\title{
ARBITRATION CLAUSES, JURY-WAIVER CLAUSES, AND OTHER CONTRACTUAL WAIVERS OF CONSTITUTIONAL RIGHTS
}

\author{
STEPHEN J. WARE* \\ INTRODUCTION
}

The Declaration of Independence refers to the rights to life, liberty, and the pursuit of happiness as inalienable. ${ }^{1}$ Some rights, however, are alienable. Consent is a common means of alienating, or "waiving, ${ }^{2}$ one's rights. In criminal procedure, for example, consent to search is a means of waiving Fourth Amendment rights. ${ }^{3}$ In family law, consent to adoption is a means of waiving parental rights. ${ }^{4}$ And in tort law, consent to bodily touching is a means of waiving rights against battery. ${ }^{5}$

While consent is a means of waiving rights in many areas of law, these areas vary in their standards of consent. For example, the standards of consent governing jury-waiver clauses tend to be higher than those governing contracts generally. ${ }^{6}$ This point is the basis for an argument that the Federal Arbitration Act (FAA) ${ }^{7}$ is unconsitutional. The FAA requires courts to apply contract-law standards of consent to arbitration agreements, ${ }^{8}$ but certain commentators argue that courts are instead constitutionally required to apply the higher standards of consent governing jury-waiver clauses. ${ }^{9}$ This Article responds to thesecommentators and argues that the FAA's contract-law standards of consent are constitutional.

Copyright $(0) 2004$ by Stephen J. Ware

This Article is also available at http://www.law.duke.edu/journals/67LCPWare.

* Professor of Law, University of Kansas.

The author thanks Tom Metzloff, Chris Drahozal, Alan Rau, Jean Stemlight, Henry Strickland, Scott Simpson, Heather Glenn, and Leigh Bullard.

1. THE DECLARATION OF INDEPENDENCE para. 2 (U.S. 1776).

2. See infra Part II for a discussion of the word "waiver" and other terminology.

3. WAyne R. LAFAVE ET AL., CRIMinal Procedure $§ 3.10$ (3d ed. 2000).

4. Homer H. Clark, JR., The LaW OF Domestic Relations in the United States $§ 20.4$ (2d ed. 1988).

5. Dan B. Dobbs, The Law of Torts $\S 95$ (2000); W. Page Keeton et Al., Prosser And KEETON ON THE LAW OF TORTS $§ 18$ (5th ed. 1984 \& Supp. 1988).

6. Jean R. Sternlight, Mandatory Binding Arbitration and Demise of the Seventh Amendment Right to a Jury Trial, 16 OHIO ST. J. ON DISP. RESOL. 669, 674 (2001).

7. 9 U.S.C. $\$ \S 16-16(2000)$.

8. See infra Part III.A.

9. See infra Part III.B. 
Part II of the Article briefly surveys the jury-trial right and the many ways in which it can be waived, including by consent to a contract containing either an arbitration clause or a jury-waiver clause. Part III contrasts the contract-law standards of consent in arbitration law with the knowing-consent standards governing jury-waiver clauses. Part IV focuses on the FAA and argues that it cannot plausibly be interpreted to require knowing consent or any other standards of consent except those used by contract law.

Part V responds to and rejects commentators' arguments that courts are constitutionally required to apply a knowing-consent standard to arbitration agreements. Part V first explains that knowing-consent standards for waivers of constitutional rights are common in the criminal context but less prevalent in the civil context. It then discusses several examples of courts' using contractlaw standards of consent for civil waivers of constitutional rights and suggests that the case law on jury-waiver clauses is an aberration because it generally uses a knowing-consent standard. Part VI suggests that the doctrinal foundations for this aberration are weak because the courts only recently adopted a knowing-consent standard for jury-waiver clauses and the Supreme Court has never done so. In sum, Part VI raises doubts about whether a knowing-consent standard is even constitutionally required for jury-waiver clauses, let alone for all civil waivers of constitutional rights.

Part VII concludes that, if the Supreme Court were to harmonize the law on civil waivers of constitutional rights by requiring that the same standard of consent be used regardless of the type of waiver or the right waived, it would likely end the knowing-consent requirement in the law governing jury-waiver clauses rather than add this requirement to arbitration and other areas of law-and rightly so. ${ }^{10}$

10. Because it is a topic rich enough for a separate article, arguments against harmonizing the law on civil waivers of constitutional rights, including the argument that the purposes of the Constitution are best served by continuing to require higher standards of consent for jury-waiver clauses than for arbitration clauses, are not discussed here. Several courts have taken this approach by treating the jury-trial right as one that attaches only after a party has overcome other hurdles. See, e.g., Am. Heritage Life Ins. Co. v. Orr, 294 F.3d 702, 711 (5th Cir. 2002) ("The Seventh Amendment does not confer the right to a trial, but only the right to have a jury hear the case once it is determined that the litigation should proceed before a court. If the claims are properly before an arbitral forum pursuant to an arbitration agreement, the jury trial right vanishes.") (quoting Cremin v. Merrill Lynch, Pierce, Fenner \& Smith, Inc., 957 F. Supp. 1460, 1471 (N.D. Ill. 1997)); Sydnor v. Conseco Fin. Servicing Corp., 252 F.3d 302, 307 (4th Cir. 2001) ("[T]he right to a jury trial attaches in the context of judicial proceedings after it is determined that litigation should proceed before a court."); Geldermann, Inc. v. CFTC, 836 F.2d 310, 323-24 (7th Cir. 1987) ("In a non-Article III forum the Seventh Amendment simply does not apply. Because we hold that Geldermann is not entitled to an Article III forum, the Seventh Amendment is not implicated.") (citations omitted).

Professor Jean Sternlight rejects this approach, calling it "[c]ircular and [i]llegitimate," as well as "absurd[]." See Sternlight, supra note Error! Bookmark not defined., at 719, 725. But there is an argument-based on viewing the Seventh Amendment jury-trial right not just as the individual right of the litigant, but also as a structural constraint on the power of federal judges - that the Constitution supports a higher standard of consent for jury-waiver clauses than for arbitration clauses. See Deborah J. Matties, Note, A Case for Judicial Self-restraint in Interpreting Contractual Jury Trial Waivers in Federal Court, 65 GEO. WASH. L. REV. 431, 464 (1997) ("[A]rbitration decreases judges' power, which 


\section{THE RIGHT TO JURY TRIAL AND CONSENT TO WAIVE IT}

The Seventh Amendment provides that "[i]n suits at common law, where the value in controversy shall exceed twenty dollars, the right of trial by jury shall be preserved." ${ }^{11}$ The Amendment applies only in federal court, ${ }^{12}$ but nearly all state constitutions contain a provision that similarly protects the right to trial by jury. ${ }^{13}$ Courts generally interpret federal and state constitutional provisions to confer a jury-trial right only in cases arising at law, as opposed to cases in equity. ${ }^{14}$ In addition to constitutional jury-right provisions, some federal and state statutes also grant jury-trial rights. ${ }^{15}$ But there are generally no jury-trial rights in adjudications outside of courts, such as those before administrative agencies or arbitrators.

The jury-trial right, like many other rights, is alienable. ${ }^{16}$ One way to alienate the jury-trial right is to consent to a contract containing an arbitration clause-that is, a clause purporting to waive the right to have disputes resolved in litigation and to create the right to have them resolved by arbitration. An enforceable arbitration clause covering a dispute means that arbitration replaces litigation with respect to that dispute. "Disputing parties who have previously agreed to arbitrate can contract into some other process of dispute resolution, but if they do not do so then each party has the right to have the dispute resolved in arbitration. ${ }^{17}$

is not contrary to the purposes of the Seventh Amendment, whereas contractual jury waivers increase judges' power, which is contrary to the purposes of the Seventh Amendment.").

11. U.S. CONST. amend. VII.

12. The Seventh Amendment is not among those the Supreme Court has interpreted as incorporated against the states through the Fourteenth Amendment. See Curtis v. Loether, 415 U.S. 189,192 n.6 (1974) ("The Court has not held that the right to jury trial in civil cases is an element of due process applicable to state courts through the Fourteenth Amendment."); Minneapolis \& St. Louis R.R. v. Bombolis, 241 U.S. 211, 217 (1916) (stating that the Amendment applies only to proceedings brought in federal court).

13. Martin H. Redish, Legislative Response to the Medical Malpractice Insurance Crisis: Constitutional Implications, 55 TEX. L. REV. 759, 797 (1977).

14. Stephen J. Ware, Alternative Dispute Resolution § 2.55(a) (2001) (citing Feltner v. Columbia Pictures Television, Inc., 523 U.S. 340, $347-48$ (1998); Motor Vehicle Mfrs. Ass'n v. New York, 551 N.Y.S.2d 470 (1990)).

15. See, e.g., Age Discrimination in Employment Act Amendments of 1978, Pub. L. No. 95-256, $\S$ 4, 92 Stat. 189, 190 (1978); see also Ellen E. Sward, Legislative Courts, Article III, and the Seventh Amendment, 77 N.C. L. REV. 1037, 1040 n.11 (1999).

16. One can alienate one's rights in two ways: in exchange for consideration or in the absence of consideration. To put it another way, one can trade away one's rights, or one can give away one's rights. In some legal contexts, such as contract law, the term "waiver" is often used to refer only to giving away one's rights. Standard accounts of contract law, for example, carefully distinguish the "waiver" of contractual rights, which does not require consideration, from the "modification" of contractual rights, which does. See, e.g., E. Allan FARnswORTH, CONTRACTS $\S 8.5$ (3d ed. 1999). In discussions of the jury-trial right, however, "waiver" seems to be used more broadly to refer both to giving away and to trading away one's right to a jury trial. This Article will conform to that custom, even though I probably would have chosen the term "exchange" if I were writing on a clean slate. The jurytrial "waivers" discussed in this Article are "exchanges"—-that is, cases in which the jury-trial right is being exchanged, along with other rights, for consideration as part of a contract.

17. WARE, supra note $14, \S 1.7(\mathrm{~b})$. 
Another way to waive the jury-trial right is to consent to a contract containing a jury-waiver clause. Unlike arbitration clauses, jury-waiver clauses neither waive the right to have disputes resolved in litigation nor create the right to have disputes resolved by arbitration. Jury-waiver clauses only purport to waive the right to have disputes resolved by a jury, replacing it with the bench trial as the default process of dispute resolution.

III

\section{CONTRACT-LAW STANDARDS VERSUS KNOWING CONSENT}

While the law governing arbitration clauses and that governing jury-waiver clauses both make consent a means of waiving the jury-trial right, they differ in their standards of consent. Arbitration-law standards of consent tend to be lower than the standards of consent used in the case law governing jury-waiver clauses. In other words, courts are quicker to enforce arbitration clauses than jury-waiver clauses.

\section{A. Arbitration/Contract-Law Standards of Consent}

Arbitration-law standards of consent are contract-law standards of consent. This is so because section 2 of the Federal Arbitration Act provides that a "written provision ... to settle by arbitration a controversy thereafter arising out of such contract or transaction ... shall be valid, irrevocable, and enforceable, save upon such grounds as exist at law or in equity for the revocation of any contract. ${ }^{18}$ The FAA applies to nearly all arbitration agreements ${ }^{19}$ and, like all federal law, it preempts inconsistent state law. ${ }^{20}$ The FAA does not, however, preempt all state law pertaining to arbitration agreements. In fact, it expressly adopts some state contract law by compelling courts to enforce arbitration agreements "save upon such grounds as exist at law or in equity for the revocation of any contract." 21 Thus, as the Supreme Court explained in Doctor's Associates v. Casarotto, ${ }^{22}$

generally applicable contract defenses, such as fraud, duress or unconscionability, may be applied to invalidate arbitration agreements without contravening $\S 2$.

Courts may not, however, invalidate arbitration agreements under state laws applicable only to arbitration provisions. By enacting $\S 2$, we have several times said, Congress precluded States from singling out arbitration provisions for suspect status, requiring instead that such provisions be placed "upon the same footing as other contracts. ${ }^{23}$

18. 9 U.S.C. $\S 2$ (2000).

19. See Allied-Bruce Terminix Cos. v. Dobson, 513 U.S. 265, 273-77 (1995); Southland Corp. v. Keating, 465 U.S. 1, 15-16 (1984).

20. See generally U.S. CONST. art. VI, cl. 2 ("This Constitution ... shall be the Supreme Law of the Land.").

21. 9 U.S.C. $\$ 2$.

22. 517 U.S. 681 (1996).

23. Id. at 686-87 (citations omitted); see also First Options of Chi., Inc. v. Kaplan, 514 U.S. 938, 944 (1995) ("When deciding whether the parties agreed to arbitrate a certain matter ... courts generally ... should apply ordinary state law principles that govern the formation of contracts."). 
This legal doctrine is at the center of the current controversy over arbitration law. The FAA makes enforcement of arbitration agreements turn on contractlaw standards of consent, but many critics of the FAA argue that enforcement of arbitration agreements should turn on other, more exacting, standards. ${ }^{24}$

The FAA's contractual approach finds consent to arbitrate if the contractlaw doctrine of mutual assent is satisfied. ${ }^{25}$ Importantly, contract law generally treats consent as an objective, rather than a subjective, phenomenon. ${ }^{26}$ In particular, formation of a contract requires, not mutual assent, but mutual manifestations of assent. "The requirement to form a contract is not that parties actually assent to its terms. ... [but] that they take actions-such as signing their names on a document or saying certain words-that would lead a reasonable person to believe that they have assented to the terms of the contract." ${ }^{27}$

The objectivity in contract law's treatment of consent has enormous implications for form contracts, the documents millions of people routinely sign without reading, let alone understanding. Under contract law's objective standards of consent, signing (or otherwise manifesting assent to) such a document is, with few exceptions, consent to the terms on the document. ${ }^{28}$ The signature's "blanket assent" is good enough. Neither reading nor understanding the terms is necessary to make those terms enforceable. ${ }^{29}$

As with contracts generally, courts find consent to arbitration in the vast majority of form contracts containing arbitration clauses. The nondrafting party (a consumer, for example) consents to arbitration by signing the form or by manifesting assent in another way, such as by performance of the contract. That the consumer did not read or understand the arbitration clause does not prevent the consumer from consenting to it. Nor does the consumer's ignorance that an arbitration clause is included on the form. These are statements of ordinary, plain-vanilla contract law. They are not statements of law peculiar to arbitration clauses. They are the way contract law treats form contract terms generally. The norm in contract law is consent to the unknown.

But, as in contract law generally, there are exceptions. Despite a signature or other "blanket" assent to a form, courts may find a lack of consent to some

24. See infra Part III.B. Of course, more exacting standards of consent would be consistent with the FAA if contract law were to adopt them. A particular state, for example, could make the lack of knowing consent a ground for the revocation of any contract, which would make it a valid ground for the revocation of arbitration agreements governed by that state's law.

25. The requirement of mutual assent "is implicit in the principle that contractual liability is consensual." FARNSWORTH, supra note 16, § 3.1 .

26. See id. $\$ \$ 3.6,3.9$.

27. Stephen J. Ware, Employment Arbitration and Voluntary Consent, 25 HOFSTRA L. REV. 83, 113 (1996) (citing FARNSWORTH, supra note 16, § 3.6) (emphasis added).

28. See, e.g., RESTATEMENT (SECOND) OF CONTRACTS $§ 211$ \& cmt. b (1981).

29. Of course, non-contract law, such as that enacted through legislation or administrative agency regulation, can override contract-law standards of consent respecting particular types of form contracts. See id., cmt. c. But no such overriding limitations govern consent to arbitration, even in the consumer context, and the legislation governing arbitration, the FAA, uses contract-law standards of consent. 
terms - including arbitration clauses_-holding them "unconscionable. ${ }^{130}$ This lack of consent in the process of contract formation falls under the under the rubric of "procedural" unconscionability. It encompasses "not only the employment of sharp practices and the use of fine print and convoluted language, but a lack of understanding and an inequality of bargaining power. ${ }^{131}$

Most statements of the law of unconscionability now hold that both procedural and substantive unconscionability [which addresses terms that are unreasonably favorable to one side] are required before courts will grant relief from a challenged term. Judicial decisions have not consistently followed this principle, however, and some courts have suggested a vaguely mathematical metaphor in which a large amount of one type of unconscionability can make up for only a small amount of the other. ${ }^{32}$

Dozens of reported decisions have held arbitration clauses unconscionable. ${ }^{33}$ All or nearly all of them involve form contracts and what is often referred to as "unequal bargaining power." ${ }^{34}$ In short, under the contractual approach of the FAA, courts find consent to arbitration with respect to the vast majority of form contracts containing arbitration clauses, but in a significant minority of them, consent is vitiated as procedurally unconscionable.

\section{B. A Noncontractural Standard: Knowing Consent}

The noncontractual approach advocated by the FAA's critics would find a lack of consent far more often than the FAA's contractual approach. That the critics' desired standards of consent are more exacting than those of the FAA is apparent from the critics' statements about case law under the FAA. One of these critics, Katherine Van Wezel Stone, charges that "in many recent cases, courts have applied attenuated notions of consent, compelling arbitration when consent is thin, if not outright fictitious. ${ }^{135}$ Another critic, Jeffrey Stempel,

30. Other courts have relied on the duty of good faith, see Hooters of Am., Inc. v. Phillips, 173 F.3d 933, 935, 940 (4th Cir. 1999), or the reasonable expectations doctrine, see Broemmer v. Abortion Servs. of Phoenix, 840 P.2d 1013 (Ariz. 1992).

31. FARNSWORTH, supra note $16, \S 4.28$.

32. Richard Craswell, Property Rules and Liability Rules in Unconscionability and Related Doctrines, 60 U. CHI. L. REV. 1, 17-18 (1993).

33. Many of these cases are cited in WARE, supra note 14, $\S 2.25$, and Stephen J. Ware, Paying the Price of Process: Judicial Regulation of Consumer Arbitration Agreements, 2001 J. DISP. RESOL. 89, 94 n.36, 96 n.40, 97 n.49, 98 n.61.

34. While this phrase "has never been successfully defined," Craswell, supra note 32, at 50 n.99, it seems to be a euphemism for disparities in wealth and experience in business; parties with substantial wealth and experience in business are described as having more "bargaining power" than parties with little. See, e.g., Todd D. Rakoff, Contracts of Adhesion: An Essay in Reconstruction, 96 HARV. L. REV. 1173, 1249 (1983) (equating "gross inequality of bargaining power" with "a wide disparity of economic resources"); Jean R. Sternlight, Panacea or Corporate Tool? Debunking the Supreme Court's Preference for Binding Arbitration, 74 WASH. U. L.Q. 637, 637 (1996) (contrasting "[1]arge companies such as banks, hospitals, brokerage houses[,] and even pest exterminators" with "customers, employees, franchisees[,] and other little guys").

35. Katherine Van Wezel Stone, Rustic Justice: Community and Coercion Under the Federal Arbitration Act, 77 N.C. L. REV. 931, 962 (1999). 
attacks the "unrealistic, formal and narrow view of contract consent and meaning demonstrated in recent [arbitration] cases. ${ }^{136}$

Possible alternatives to the FAA's contract-law standards of consent are many, but the FAA's critics appear to be coalescing around standards that would require knowing consent. The Ninth Circuit, which seems to be the circuit least inclined to find an enforceable arbitration agreement, ${ }^{37}$ has used a knowing-consent standard in refusing to enforce certain arbitration clauses. ${ }^{38}$ Other judges, such as Alabama Chief Justice Roy Moore, have also used a knowing-consent standard. ${ }^{39}$

A knowing-consent standard is perhaps most thoughtfully advocated by Jean Sternlight, a vigorous critic of the FAA's contractual approach. ${ }^{40}$ Professor

36. Jeffrey W. Stempel, Bootstrapping and Slouching Toward Gomorrah: Arbitral Infatuation and the Decline of Consent, 62 BROOK. L. ReV. 1381, 1384 n.8 (1996); see also Paul D. Carrington \& Paul H. Haagen, Contract and Jurisdiction, 1996 SUP. CT. REV. 331, passim (describing consumer arbitration agreements not as products of mutual consent, but as "predation" by those with "economic power" on those lacking such power); David S. Schwartz, Enforcing Small Print to Protect Big Business: Employee and Consumer Rights Claims in an Age of Compelled Arbitration, 1997 WIS. L. REV. 33, 58 ("[I]f an arbitration clause has been inserted in a contract of adhesion on a 'take-it-or-leave-it' basis, it is difficult to characterize it as the product of 'consent,', 'agreement' or 'bargaining.' ").

37. See, e.g., Circuit City Stores, Inc. v. Adams, 194 F.3d 1070 (9th Cir. 1999) (holding that the FAA did not cover an agreement to arbitrate employment claims), rev'd, 532 U.S. 105 (2001), on remand, 279 F.3d 889 (9th Cir. 2002) (concluding that the agreement was both procedurally and substantively unconscionable); Duffield v. Robertson Stephens \& Co., 144 F.3d 1182 (9th Cir. 1998) (refusing to enforce an agreement to arbitrate Title VII claims), overruled by EEOC v. Luce, Forward, Hamilton \& Scripps, LLP, 345 F.3d 742, 749 (9th Cir. 2003) (en banc).

38. See Nelson v. Cyprus Bagdad Copper Corp., 119 F.3d 756, 761 (9th Cir. 1997) (requiring "at least a knowing agreement to arbitrate employment disputes") (quoting Prudential Ins. Co. v. Lai, 42 F.3d 1299, 1304 (9th Cir. 1994)); Prudential, 42 F.3d at 1305 ("[W]e conclude that a Title VII plaintiff may only be forced to forego her statutory remedies and arbitrate her claims if she has knowingly agreed to submit such disputes to arbitration.").

39. See Ex parte Allen, 798 So. 2d 668, 676-77 (Ala. 2001) (Moore, C.J., concurring).

40. In Panacea or Corporate Tool? Debunking the Supreme Court's Preference for Binding Arbitration, Professor Sternlight argues that "Congress should amend the FAA to effectively reverse the Court's ruling [in Doctor's Associates v. Casarotto, 517 U.S. 681, 687 (1996)], protect weaker parties, and ensure the constitutionality of the FAA," and that "states should be allowed to enact legislation designed to ensure that agreements are entered knowingly and voluntarily." Sternlight, supra note 34, at 707. In Rethinking the Constitutionality of the Supreme Court's Preference for Binding Arbitration, 72 TuL. L. REV. 1, 59 (1997) [herinafter Sternlight, Rethinking], she discusses the standards of consent required by constitutional provisions, including the Seventh Amendment, and argues for a standard "sufficient to protect ignorant employees and consumers from unwittingly waiving their rights to a jury trial, an Article III judge, and due process." And in Mandatory Binding Arbitration and Demise of the Seventh Amendment Right to a Jury Trial, she argues directly that the Seventh Amendment requires courts to apply knowing-consent standards to arbitration agreements. See Sternlight, supra note Error! Bookmark not defined., passim.

With varying degrees of specificity, several other scholars have indicated that they share the view that the Seventh Amendment requires a knowing-consent standard for arbitration agreements. See Edward Brunet, Arbitration and Constitutional Rights, 71 N.C. L. REv. 81, 102-13 (1992); Richard C. Reuben, Constitutional Gravity: A Unitary Theory of Alternative Dispute Resolution and Public Civil Justice, 47 UCLA L. REV. 949, 1019-34 (2000); Richard E. Speidel, Contract Theory and Securities Arbitration: Whither Consent?, 62 BROOK. L. REV. 1335, 1352 n.63 (1996); Stempel, supra note 36, at 1389-93. 
Sternlight explains how knowing-consent standards for jury-waiver clauses differ from the contract-law standards of consent used in arbitration cases: ${ }^{41}$

While courts have not adopted an identical phrasing of the factors to be considered in examining contractual jury trial waivers, there is substantial agreement regarding what kinds of information is relevant. Courts typically consider any actual negotiations over the clause, whether the clause was presented on a take-it-or-leave-it basis, the conspicuousness of the waiver, the degree of bargaining disparity between the parties, and the experience and sophistication of the party opposing the waiver. Courts have not been explicit as to how these factors relate to one another, but seem to consider them all together. Thus, it is not necessary to make a strong showing on all of the factors to uphold a jury waiver clause. Equally, it is not necessary to make a strong showing on all of the factors to defeat a jury waiver clause. ${ }^{42}$

Thus, knowing-consent standards resemble, but go farther than, the unconscionability doctrine. Finding a lack of "knowing" consent seems something like a finding procedural unconscionability, which Farnsworth characterizes as "a lack of understanding and an inequality of bargaining power, ${ }^{43}$ so a knowing-consent standard may be little different from the unconscionability doctrine without the factor of substantive unconscionability. In any event, both knowing-consent standards and the unconscionability doctrine are sufficiently indeterminate that one must look at particular cases, rather than general statements of law, to appreciate the difference between knowing-consent standards and contract-law standards of consent, including those embodied in the unconscionability doctrine, and to appreciate how a knowing-consent standard would affect arbitration law and transactions using arbitration clauses. ${ }^{44}$

Most significantly, a knowing-consent standard would generally depart from contract law's norm of consent to the unknown - that is, its usual practice of finding consent to form-contract terms about which one party is ignorant. If, for example, a consumer did not know there was an arbitration clause in a form contract, then a knowing-consent standard would likely prevent enforcement of the clause. ${ }^{45}$ Such a standard might lead parties seeking to ensure the enforceability of their arbitration clauses to change how they draft documents and structure transactions. For starters, those drafting forms might put arbitration clauses in "large typeface, bold, or capital lettering [and place them] in a key location, such as near the signature line of the agreement. ${ }^{146}$

Going further, drafters who currently make the arbitration clause one paragraph of a lengthy document might restructure their transactions to have two separate documents, one containing just the arbitration clause, and the other

41. Sternlight, supra note Error! Bookmark not defined., at 680-710.

42. Id. at $680-81$.

43. FARNSWORTH, supra note $16, \S 4.8$.

44. The following paragraphs rely heavily on Professor Sternlight's research.

45. See Heller Fin., Inc. v. Finch-Bayless Equip. Co., No. 90 C 1672, 1990 WL 77500, at *2 (N.D. Ill. May 31, 1990) ("Where the [jury] waiver provision is set out in an unnegotiated form contract that is not susceptible to negotiation, it is presumed that there was not a knowing waiver of the right to a jury trial."); see also Sternlight, supra note Error! Bookmark not defined., at 681-83.

46. See Sternlight, supra note Error! Bookmark not defined., at 684-85. 
containing all the other contractual language. ${ }^{47}$ Or, if the arbitration clause is to remain part of a lengthy document, the drafter might require the consumer to separately initial the arbitration clause, in addition to signing the document as a whole. Drafters who currently rely on the consumer's performance of the contract as a manifestation of assent, such as banks and credit card issuers whose arbitration clauses appear on "stuffers" mailed with a monthly statement, might restructure their transactions to obtain the consumer's signature as a manifestation of assent to arbitration. ${ }^{48}$

Going further still, it is possible that a knowing-consent standard would require proof not only that the consumer knew there was an arbitration clause in the contract, but that the consumer read and understood the clause. ${ }^{49}$ This standard might be said to require "knowing and intelligent" consent..$^{50}$ Such a standard might lead parties seeking to ensure the enforceability of their arbitration clauses to further change how they draft documents and structure transactions. Contracts containing arbitration clauses might be accompanied by written disclosures about arbitration. ${ }^{51}$ But if we cannot be confident that consumers will read arbitration agreements before signing them, how can we be confident that they will read disclosures about arbitration before proceeding with the transaction? This problem might lead a "knowing and intelligent" standard of consent to require drafting parties to provide oral explanations of arbitration..$^{52}$ Just as police officers are trained to give oral Miranda warnings about the right to remain silent and the right to a lawyer, parties drafting and using arbitration agreements would train their frontline personnel to give oral explanations of the jury-trial right and other rights waived through an arbitration agreement. ${ }^{53}$ These explanations might be videotaped so that the tape could be introduced into evidence in the event of litigation over their content or quality. ${ }^{54}$

But how can we be confident that consumers will understand the oral explanations they receive? This problem might lead a "knowing and intelligent"

47. See Motoko Rich \& John D. McKinnon, Do Arbitration Pacts Steer Car Buyers Wrong Way?, Wall ST. J. (Southeast Journal), Nov. 26, 1997, at S1 (reporting that the president of the Automobile Dealers Association of Alabama "says his group has urged dealers to print the arbitration clauses on separate pieces of paper and introduce them early in the contract signing process").

48. See Sternlight, supra note Error! Bookmark not defined., at 690.

49. See id. at 682 ("Courts also examine the discussions, if any, surrounding inclusion of the [jurywaiver] clause. They are more likely to uphold clauses that were accurately explained.").

50. See id. at 679 (noting that "knowing and intelligent" is one of many phrases courts use without making distinctions among them).

51. See id. at 682 .

52. Id.

53. See generally Clark Freshman, Tweaking the Market for Autonomy: A Problem-Solving Perspective on Informed Consent in Arbitration, 56 U. MIAMI L. REV. 909 (2002) (discussing the practical problems in determining what should be disclosed about arbitration).

54. See, e.g., Stout v. J.D. Byrider, 228 F.3d 709, 713 (6th Cir. 2000 ) ("Closings at the Sandusky dealership are videotaped by a wall mounted camera for training and quality assurance purposes."); Earle Eldridge, More Car Dealers Now Videotape Sales, USA TODAY, July 3, 2001, available at http://www.usatoday.com/money/autos/2001-07-03-on-tape.htm. 
standard of consent to require consumers to take an exam on arbitration. This exam could be an oral exam given by the judge in open court: judges would question consumers about their decision to consent to arbitration, much the way judges now question criminal defendants about their decisions to plead guilty or to try their cases without a lawyer. ${ }^{55}$ Alternatively, instead of trying to enable the consumer to make a "knowing and intelligent" choice, the law could permit the consumer's lawyer to make such a choice. A "knowing and intelligent" consent standard might be satisfied if the consumer hires a lawyer who signs an affidavit opining that it is in the consumer's best interests to consent to the arbitration agreement. ${ }^{56}$ This would be analogous to the "undue hardship" affidavits signed by lawyers who represent individual debtors seeking to reaffirm debts that would otherwise be discharged in bankruptcy. ${ }^{57}$

In sum, a knowing-consent standard could be far more exacting than the FAA's contractual standards of consent, and this would result in courts finding consent in far fewer arbitration agreements. This might well be the case in virtually all agreements involving consumers, employees, and other ordinary individuals who did not first have a lawyer review the agreement. And even the mildest step toward knowing consent-requiring arbitration clauses to be prominently displayed-would be more exacting than the FAA's contract-law standards of consent. ${ }^{58}$

\section{IV}

\section{THE FAA'S CONTRACT-LAW STANDARDS OF CONSENT: LEGISLATIVE HISTORY AND STATUTORY INTERPRETATION}

Because FAA section 2 adopts contract law's standards of consent, a knowing-consent standard would be inconsistent with the FAA. This view is based on the language of the FAA and Supreme Court jurisprudence, including, most recently, Doctor's Associates v. Casarotto ${ }^{59}$ in which eight justices joined the Court's opinion. ${ }^{60}$ Even before Casarotto, the leading arbitration treatise rec-

55. LAFAVE ET AL., supra note Error! Bookmark not defined., §11.3(b).

56. See Sternlight, supra note Error! Bookmark not defined., at 687-89 ("When a relatively weak party is represented by an attorney, some courts have found that the representation is sufficient to allay concerns about the party's lack of bargaining power.").

57. See 11 U.S.C. § 524(c)(3) (2000).

58. See Doctor's Assocs. v. Casarotto, 517 U.S. 618, 687 (1996) (holding that the FAA preempts a Montana statute requiring that contracts containing arbitration clauses provide notice of the arbitration clause in "underlined capital letters on the first page of the contract").

59. 517 U.S. 681, 687 (1996); see supra notes 22-23 and accompanying text (quoting Casarotto).

60. Casarotto involved a Montana statute requiring that, "[n]otice that a contract is subject to arbitration ... be typed in underlined capital letters on the first page of the contract; and unless such notice is displayed thereon, the contract may not be subject to arbitration." MONT. CODE ANN. § 27-5-114(4) (1995) (repealed 1997). The Supreme Court held that the statute was preempted by the FAA because it "condition[ed] the enforceability of arbitration agreements on compliance with a special notice requirement not applicable to contracts generally." 517 U.S. at 687. As the Supreme Court stated, the FAA "precluded States from singling out arbitration provisions for suspect status, requiring instead that such provisions be placed 'upon the same footing as other contracts.'" Id. (quoting Scherk v. Alberto-Culver Co., 417 U.S. 506, 511 (1974)). Justice Thomas's lone dissent related not to the stan- 
ognized that laws "requiring greater information or choice in the making of agreements to arbitrate than in other contracts" are inconsistent the FAA. ${ }^{61}$ Yet, Professor Sternlight rejects the view that application of knowing-consent standards would "clearly be inconsistent with the FAA's statutory language requiring that courts enforce predispute arbitration agreements 'save upon such grounds as exist at law or in equity for the revocation of any contract. " 62

While some courts have construed that language to support only common law contractual defenses such as unconscionability and fraud, there is no reason why the principles of contract interpretation deriving from the Seventh Amendment would not be considered to be grounds "at law or in equity." Any contract calling for waiver of a constitutional right, including a jury trial right, must be examined to ensure that it is voluntary, knowing and intelligent. ${ }^{6}$

The flaw in this argument is that the truth of its last sentence requires the words "calling for waiver of a constitutional right, including a jury trial right." Had the sentence omitted these words, and read, "Any contract must be examined to ensure that it is voluntary, knowing and intelligent," it would have been false. $^{64}$ The FAA's language refers to grounds for the revocation of "any contract," not "any contract calling for waiver of a constitutional right, including a jury trial right." As Casarotto points out, grounds "such as fraud, duress or unconscionability" are grounds for the revocation of any contract. ${ }^{65}$ The lack of

dard of consent required by section 2, but to whether the FAA applies in state as well as federal court. See 517 U.S. at 690 (Thomas, J., dissenting).

For other Supreme Court cases, see, for example, First Options of Chi., Inc. v. Kaplan, 514 U.S. 938, 944 (1995) ("When deciding whether the parties agreed to arbitrate a certain matter ... courts generally ... should apply ordinary state law principles that govern the formation of contracts."); Perry v. Thomas, 482 U.S. 483, 492 n.9 (1987) ("[S]tate law, whether of legislative or judicial origin, is applicable if that law arose to govern issues concerning the validity, revocability, and enforceability of contracts generally. A state law principle that takes its meaning precisely from the fact that a contract to arbitrate is at issue does not comport with [the text of Section 2].").

The Supreme Court continues to reiterate that "the FAA's purpose [is] 'to reverse the longstanding judicial hostility to arbitration agreements ... and to place arbitration agreements upon the same footing as other contracts.'" Green Tree Fin. Corp.-Ala. v. Randolph, 531 U.S. 79, 89 (2000) (quoting Gilmer v. Interstate/Johnson Lane Corp., 500 U.S. 20, 24 (1991)).

61. See 2 IAn R. MACNEIL ET AL., Federal ARbitration LaW § 19.1.1, 19:4-19:5 (1995) (stating that under Southland and Perry, "state legislation requiring greater information or choice in the making of agreements to arbitrate than in other contracts is preempted" by section 2). While Macneil et al. were writing about state law, which is preempted when inconsistent with the FAA, their point about what law is inconsistent with the FAA applies with equal force to federal law, which is not preempted because of such inconsistency.

62. Sternlight, supra note Error! Bookmark not defined., at 718.

63. Id.

64. See supra Part III.A.

65. Doctor's Assocs. v. Casarotto, 517 U.S. 681, 687 (1996). Some courts take the phrase "any contract" more seriously than others. In KKW Enterprises v. Gloria Jean's Gourmet Coffees Franchising Corp., 184 F.3d 42 (1st Cir. 1999), the First Circuit took the phrase seriously:

Here, the Rhode Island statute states that: "A provision in a franchise agreement restricting jurisdiction or venue to a forum outside this state ... is void with respect to a claim otherwise enforceable under this act." R.I. Gen. Laws § 19-28.1-14. Because this proscription limits the statute's application to one type of provision, venue clauses, in one type of agreement, franchise agreements, the statute does not apply to any contract. Writ simple, because $\S 19$ 28.1-14 is not a generally applicable contract defense, it is, if applied to arbitration agreements, preempted by $\S 2$ of the FAA. 
knowing consent is not. Therefore, it would be very surprising if the Supreme Court interpreted FAA section 2 to require knowing consent. So long as the Court continues to interpret section 2 to require contract-law standards of consent, the Court can only accept the argument that the Seventh Amendment requires "knowing" consent to arbitration clauses if it is willing to hold section 2 unconstitutional. ${ }^{66}$

A holding that section 2 is unconstitutional would be startling. The FAA was enacted more than three-quarters of a century ago. Since that time, no published judicial decision has ever found section 2's contract-law standards of consent to be inconsistent with the Seventh Amendment. ${ }^{67}$ Apparently, no commentator even suggested this argument until the FAA's sixth decade of existence. $^{68}$ It is true that, for most of the FAA's life, courts interpreted it to apply only in federal, not state, courts. ${ }^{69}$ But this does not explain why an inconsistency between the FAA and the Seventh Amendment, both of which have applied in federal court since 1925, would have been missed for so long.

Id. at 50-51. In contrast is the approach of the Montana Supreme Court in Keystone, Inc. v. Triad Systems Corp., 971 P.2d 1240, 1245-46 (Mont. 1998), the opinion for which was written by Justice Trieweiler, the author of an impassioned anti-arbitration opinion in Casarotto. See Casarotto v. Lombardi, 886 P.2d 931, 939 (Mont. 1994) (Trieweiler, J., concurring), rev'd sub nom. Doctor's Assocs. v. Casarotto, 517 U.S. 681 (1996). In Keystone, the court held that Montana statutes voiding out-of-state forum-selection clauses do "not conflict with the FAA" because they do not single out arbitration clauses, but apply to both arbitration clauses and forum-selection clauses in contracts generally. 971 P.2d at 1245 . The statutes do not, in fact, apply to "any contract" because they do not apply to contracts lacking forum-selection clauses. See Christopher R. Drahozal, Federal Arbitration Act Preemption, 79 InD. L.J. 393, 409-10 (2004); Stephen J. Ware, Contractual Arbitration, Mandatory Arbitration, and State Constitutional Jury-Trial Rights, 38 U.S.F. L. Rev. 39, $46-48$ (2003).

66. Stephen J. Ware, Consumer Arbitration as Exceptional Consumer Law, 29 MCGEORGE L. REV. 195, 216-17 (1998); accord Sternlight, supra note Error! Bookmark not defined., at 718 ("However, if Professor Ware's more narrow interpretation of the FAA prevails, and courts interpret Section 2 of the FAA to foreclose use of the standard Seventh Amendment waiver analysis, then he is correct that Section 2 is unconstitutional.").

67. Professor Sternlight "located just one opinion in which a federal court refused to enforce a contractual arbitration clause on the ground that it violated the Seventh Amendment." This unpublished decision was reversed on appeal. See Sternlight, supra note Error! Bookmark not defined., at 711 (citing Sydnor v. AAPCO of Richmond W., No. 3:00 CV 396 (E.D. Va. Sept. 27, 2000) (transcript of opinion issued from bench on file with author), rev'd sub nom. Sydnor v. Conseco Fin. Serv. Corp., 252 F.3d 302, 206-07 (4th Cir. 2001) (per curiam) (noting that the parties signed a clause stating that they voluntarily and knowingly waived their jury-trial rights, and rejecting the argument that the waiver of jury trial calls for a more demanding standard).

68. See supra note 40. A possible earlier example is Edward L. Rubin, Toward a General Theory of Waiver, 28 UCLA L. REV. 478 (1981). Professor Rubin argued that "the contract standard cannot be used to justify those waivers that involve constitutional rights since such rights necessarily take precedence over the contract policy of honoring private agreements." Id. at 545 . However, this argument was not directed at section 2 of the FAA in particular.

Though the argument that section 2's contract-law standards of consent are unconstitutional because of an inconsistency with the Seventh Amendment is recent, there are much older challenges to state arbitration statutes based on jury-trial provisions of state constitutions. See, e.g., Berkovitz v. Arbib \& Houlberg, 130 N.E. 288 (N.Y. 1921); see also infra notes 199-200 and accompanying text (discussing Berkovitz).

69. WARE, supra note $14, \S \S 2.6-2.8$. For contrasting views on the FAA's application in state court, compare IAN R. MACNEIL, AMERICAN ARBITRATION LAW 92-121 (1992), with Christopher R. Drahozal, In Defense of Southland: Reexamining the Legislative History of the Federal Arbitration Act, 78 Notre DAME L. REV. 101 (2002). 
Another argument, suggested by Professor Sternlight, might explain why the alleged inconsistency between the FAA and the Seventh Amendment went so long unnoticed:

[T]he Federal Arbitration Act was never intended to permit companies to impose arbitration on unknowing consumers and employees, but rather was merely intended to allow two sophisticated businesses to enter into predispute arbitration agreements. The legislative history of the Act is filled with discussions of how businesses need to be able to enter into enforceable arbitration agreements with one another. In contrast, while companies in 1924 did not customarily seek to impose contracts of adhesion on a widespread basis, the FAA's legislative history does reflect legislators' concern that arbitration not be imposed through nonnegotiable contracts of adhesion in the employment or insurance context. Thus, applying the [knowing-consent standards arguably required by the] Seventh Amendment to arbitration would not undercut the policy underlying the FAA, but would instead support it. ${ }^{70}$

This argument could be read to suggest that an alleged inconsistency between the FAA and the Seventh Amendment was missed because the sorts of cases raising it (those not involving "two sophisticated businesses") did not arise until the 1980s, when arbitration clauses in employment and consumer form contracts became more common. This suggestion, though, is implausible for the following reasons.

First, the FAA did not make enforceable only arbitration agreements between "two sophisticated businesses." It made enforceable all arbitration agreements "involving commerce" ${ }^{171}$ between all sorts of parties, with the exception of "contracts of employment of seamen, railroad employees, or any other class of workers engaged in foreign or interstate commerce." ${ }^{72}$ While the legislative history reflects concern by Senator Walsh of Montana regarding other sorts of parties to form contracts, ${ }^{73}$ these concerns did not find their way into the statute.

For example, consider parties buying an insurance policy (a classic "adhesion" contract) containing an arbitration clause. The text of the FAA does not permit a reading that such insurance arbitration agreements are anything less than "valid, irrevocable, and enforceable, save upon such grounds as exist at law or in equity for the revocation of any contract." ${ }^{14}$ Congress knew how to carve

70. Sternlight, supra note Error! Bookmark not defined., at 729-30; see also Sarah Rudolph Cole, Incentives and Arbitration: The Case Against Enforcement of Executory Arbitration Agreements Between Employers and Employees, 64 UMKC L. REV. 449, 466 (1996) ("[I]t is . . clear that the drafters of the FAA did not intend to include noncommercial contracts with the requisite effects on interstate commerce within its scope."); Schwartz, supra note 36, at 75 ("On its face, the statute does not expressly limit its coverage to arbitration of any particular subject matter.... However, closer inspection of the text and legislative history strongly indicate a congressional intent to create a statute within the sphere of the commercial paradigm.").

71. 9 U.S.C. $\$ 2(2000)$.

72. $§ 1$.

73. See A Bill Relating to Sales and Contracts to Sell in Interstate and Foreign Commerce; and A Bill to Make Valid and Enforceable Written Provisions or Agreements for Arbitration of Disputes Arising Out of Contracts, Maritime Transactions or Commerce Among the States or Territories or With Foreign Nations: Hearing on S. 4213 and S. 4214 Before the Senate Comm. on the Judiciary, 67th Cong. 9-11 (1923).

74. $\$ 2$. 
out certain employees from the FAA and chose to do so. With respect to other parties, Congress chose not to create exclusions. In recent years several bills have been introduced in Congress to exclude additional parties from the FAA. ${ }^{75}$ Enactment of such bills, rather than creative interpretation of the current statute, is the legitimate way to exclude consumers or other parties from the FAA. ${ }^{76}$

Furthermore, it does not take a consumer case to raise an inconsistency between the FAA and the Seventh Amendment. If the Seventh Amendment requires knowing consent, then this requirement has long gone unmet in countless arbitration agreements between businesses. Just as consumers routinely sign form contracts without reading them, so do business people, even "sophisticated" ones. Indeed, the same human being who is a sophisticated businessperson in one transaction is a consumer in another. It is simply not true that the line between business and consumer parties is the line between knowing and unknowing consent. So even when business-to-business arbitration agreements were the only ones challenged in court, some challengers could have avoided those agreements based on a lack of "knowing" consent, had courts believed that this is required by the Seventh Amendment. ${ }^{77}$ That the pre1980s case law reveals few, if any, occasions when this knowing-consent argument was made suggests that lawyers and judges believed that the Seventh Amendment requires no more than the FAA's contract-law standards of consent. Good reasons for this belief are discussed in the following section of this Article.

75. See, e.g., Marcia Coyle, Anti-arbitration Bills Set Off a Classic Brawl, NAT'L L.J., Aug. 12, 2002, at $\mathrm{A} 8$.

76. It is true, as Jean Sternlight argues, that when the FAA was enacted "the economy looked substantially different than it looks today. There were very few transactions between large merchants and individual consumers that would have involved interstate commerce and thus fallen under the jurisdiction of the FAA." Sternlight, supra note 34, at 647. The great number of transactions now held to involve interstate commerce reflects not only an increase in long-distance consumer transactions, but also the Supreme Court's expansion of the Commerce Clause to cover transactions previously considered beyond the reach of federal legislation. See Henry C. Strickland, The Federal Arbitration Act's Interstate Commerce Requirement: What's Left for State Arbitration Law?, 21 HOFSTRA L. REV. 385, 459 (1992) ("Consumer disputes (and other disputes that are the subject of special consideration in state arbitration statutes) were unlikely to find their way to federal court in 1926 , because they seldom involved citizens of more than one state[,] and they usually did not meet the requisite amount in controversy. Indeed, Congress may have considered such disputes beyond its commerce power in 1925."). If applying the FAA to consumer contracts is inconsistent with the intent of the Congress that enacted it, that inconsistency is more properly blamed on the Court's interpretation of the Commerce Clause than on the Court's interpretation of the FAA.

77. In "numerous courts," Professor Sternlight points out, businesses have successfully avoided enforcement of jury-waiver clauses they had signed. Sternlight, supra note Error! Bookmark not defined., at 689. These cases exemplify lack of knowing consent on the part of a business. 


\title{
$\mathrm{V}$ \\ THE CONSTITUTIONALITY OF THE FAA'S CONTRACT-LAW \\ STANDARDS OF CONSENT
}

\begin{abstract}
A. The Different Consent Standards for Waiving Constitutional Rights in the Criminal and Civil Contexts
\end{abstract}

The starting point for some who discuss waivers of constitutional rights is a 1938 criminal case, Johnson v. Zerbst ${ }^{78}$ in which the Supreme Court noted that "[a] waiver is ordinarily an intentional relinquishment or abandonment of a known right or privilege. ${ }^{179}$ In a later criminal case, Brady $v$. United States ${ }^{80}$ the Court stated that "[w]aivers of constitutional rights not only must be voluntary but must be knowing, intelligent acts done with sufficient awareness of the relevant circumstances and likely consequences. ${ }^{81}$

Professor Sternlight argues that "[t]he Supreme Court has consistently employed the 'knowing, voluntary, intentional standard' for waivers of constitutional rights in the criminal context." ${ }^{82}$ But this may be misleading. Even in the criminal context, the Court has not consistently applied this standard. As Professor Sternlight has herself acknowledged, "[c]ourts have not required knowing waiver ... in connection with the rights to avoid self incrimination or to be present at one's trial, instead allowing defendants to waive these rights merely by failing to raise an objection or by taking an action contrary to the right. ${ }^{183}$ Another example, pointed out by Edward Rubin over twenty years ago, is the waiver of an accused's constitutional due process right not to stand trial before a jury while dressed in identifiable prison clothes. ${ }^{84}$ Similarly, knowing consent is not required for an accused to waive the Sixth Amendment right to be tried in the "district wherein the crime shall have been committed. ${ }^{185}$ As Rubin puts it, this is another of the rights to which "courts have applied a much less demanding waiver standard.... While these rights must be waived voluntarily, they need not be waived knowingly." ${ }^{86}$

78. 304 U.S. 458 (1938).

79. Id. at 464.

80. 397 U.S. 742 (1970).

81. Id. at 748 .

82. Sternlight, supra note Error! Bookmark not defined., at 678 n.40 ("[W]aivers of constitutional rights not only must be voluntary but must be knowing, intelligent acts done with sufficient awareness of the relevant circumstances and likely consequences.") (citing Brady v. United States, 397 U.S. 742, 748 (1970)) .

83. Id. at 709 n.185 ("A defendant who chooses to testify waives his privilege against compulsory self-incrimination with respect to testimony he gives") (quoting Harrison v. United States, 392 U.S. 219, $222(1968))$.

84. See Rubin, supra note 68, at 492 n.64 (citing Estelle v. Williams, 425 U.S. 501 (1976)).

85. U.S. CONST. amend. VI.

86. Rubin, supra note 68, at 496; see, e.g., United States v. Carreon-Palacio, 267 F.3d 381, 391 (5th Cir. 2001) ("The standard for finding a waiver of venue rights is much more relaxed than the rigorous standard for finding waivers of the right to trial by jury, the right to confront one's accusers[,] or the 
The distinction between waivers judged under the strict standard and those judged under the more lenient version of the Johnson framework is emphasized by courts' use of a subjective method of proof in the first category, and an objective method of proof in the second. When the strict standard is employed, the trial judge often examines the defendant as to his state of mind, in order to make sure that he is actually aware of his right and willing to relinquish it.... When the lenient waiver standard is used, courts employ an objective method of proof. ${ }^{87}$

While knowing consent to waive a constitutional right is sometimes not required in the criminal context, it is often not required in the civil context. According to Rubin, "[t]he Johnson framework, with its emphasis on knowledge and volition, is no longer used in civil law. Instead, civil law waivers are judged according to contract-law principles. ${ }^{188}$

\section{B. Property-Deprivation Cases}

In his discussion of civil waivers, Professor Rubin discusses arbitration agreements, settlement agreements, and consent judgments, all of which waive constitutional rights to due process and, where applicable, jury trial. ${ }^{89}$ Settlement agreements and consent decrees, however, are formed post-dispute, when parties tend to be more aware of the rights they are waiving and when parties are often represented by counsel. Cases more analogous to predispute arbitration agreements are those in which parties waive constitutional rights in a predispute contract, especially a form contract. Professor Sternlight relies on two such cases in particular, D.H. Overmyer Co. v. Frick Co., ${ }^{90}$ and Fuentes v. Shevin, ${ }^{91}$ "urg[ing] the Court to apply to arbitration agreements the civil waiver standard it has begun to develop" in these cases. ${ }^{2}$ This urging, however, is based on a dated reading of constitutional law. The Supreme Court and its rulings have evolved in significant ways since these 1972 cases.

Overmyer was an Ohio case involving a cognovit note, an "ancient legal device by which the debtor consents in advance to the holder's obtaining a judgment without notice or hearing, and possibly even with the appearance, on

privilege against compulsory self incrimination.")(quoting United States v. Winship, 724 F.2d 1116, 1124 (5th Cir. 1984)).

87. Rubin, supra note 68, at 497.

88. Id. at 512. This distinction between the criminal and civil contexts is questioned by Professor Sternlight, who says that "[a] strong argument can be made that the Court should apply the criminal standard in the civil context as well .... The Court has, after all, never explained why constitutionally protected rights should be afforded any less protection in the civil context than in the criminal context." Sternlight, Rethinking, supra note 40, at 56-57. Perhaps the explanation is simply that the law in this area, as in so many others, is more protective of criminal defendants than of parties to civil actions because the consequences of losing tend to be so much more severe. There is, however, another possible explanation: In the civil context, parties who waive their constitutional rights nearly always do so as part of a contract, a context in which there is "far less danger of overreaching and duress by the party seeking to enforce the waiver." L\&R Realty v. Conn. Nat'l Bank, 715 A.2d 748, 755 (Conn. 1998) (concluding that "it is appropriate to apply a lower standard in determining the enforceability of prelitigation contractual jury trial waivers than for waivers in criminal cases").

89. Rubin, supra note 68 , at 512-21.

90. 405 U.S. 174 (1972).

91. 407 U.S. 67 (1972).

92. Sternlight, Rethinking, supra note 40 , at 57. 
the debtor's behalf, of an attorney designated by the holder." ${ }^{93}$ Unlike other states at that time ${ }^{94}$ Ohio law permitted cognovits. The law allowed " a court ... the power to open the judgment upon a proper showing, ${ }^{195}$ making it possible for a debtor who had signed a cognovit to ultimately avoid judgment on the debt. Nevertheless, a cognovit is a waiver of the debtor's constitutional due process rights to notice and a hearing prior to the entry of judgment. ${ }^{96}$

The Overmyer Court enforced this predispute waiver of constitutional rights. It did so, however, in the context of a negotiated agreement between two corporations represented by lawyers; the Overmyer case did not involve a form contract presented take-it-or-leave-it to an unrepresented consumer. ${ }^{97}$ The Overmyer Court carefully refrained from holding that the knowing-consent standard of criminal cases like Brady and Johnson applies in the civil context. ${ }^{98}$ The Court pointed out that Overmyer was a corporation and that its agreement "was not a contract of adhesion." knowing - a stark contrast to the unknowing consent routinely given to the terms of form contracts.

Fuentes, on the other hand, involved consumer form contracts. The consumers had purchased goods under "conditional sales contract[s] calling for monthly payments over a period of time." ${ }^{100}$ Under the law of the Fuentes era, the seller retained title to the goods until the consumer paid the debt. Under modern state law, Article 9 of the Uniform Commercial Code, these transaction are treated as sales, with title passing to the consumer, but with the seller retaining a security interest - that is, a consensual lien. ${ }^{101}$ Under both Article 9 and the state law in Fuentes, if the consumer-debtor defaults then the sellercreditor may obtain possession of the goods through a replevin action by which a court orders a sheriff or other state actor to take the goods from the consumer. $^{102}$ The state replevin statutes in Fuentes permitted creditors, upon ex parte application to a court clerk and the posting of a bond, to obtain a writ of replevin instructing the sheriff to seize the goods. ${ }^{103}$ Seizure occurred without

\footnotetext{
93. 405 U.S. at 176.

94. Id. at 177.

95. Id. at $184-85$.

96. Id. at 184 .

97. According to Richard Shell,
}

Overmyer involved a construction subcontract in which the contractor, which had agreed to pay the subcontractor by progress payments, fell behind in its payments. Eventually, after several rounds of bargaining, which included attorneys for both sides, the contractor negotiated a new payment schedule at a lower rate of interest in exchange for a contract that contained the cognovit provision.

G. Richard Shell, Contracts in the Modern Supreme Court, 81 CAL. L. REV. 433, 477 n.270 (1991).

98. 405 U.S. at 185.

99. Id. at 186.

100. Fuentes v. Shevin, 407 U.S. 67, 70 (1972) (plurality decision).

101.See UCC \$ 1-201(35) (amended 2003).

102. 407 U.S. at 78 n.7.

103. Id. 
the debtor receiving notice or the opportunity for a hearing, so the Court held that the debtors were deprived of their property without due process of law. ${ }^{104}$

In Fuentes, the Court distinguished its holding from that of Overmyer by emphasizing the different types of consent given in the two cases. Unlike Overmyer, the parties in Fuentes "were far from equal in bargaining power," and the "waiver provision was a printed part of a form sales contract." 105 The Court held that a "waiver of constitutional rights in any context must, at the very least, be clear," and that it need not consider "the involuntariness or unintelligence of a waiver when the contractual language relied upon does not, on its face, even amount to a waiver." ${ }^{106}$ There was no clear waiver because the contracts

simply provided that upon a default the seller 'may take back,' 'may retake' or 'may repossess' merchandise. The contracts included nothing about the waiver of a prior hearing. They did not indicate how or through what process - a final judgment, selfhelp, prejudgment replevin with a prior hearing, or prejudgment replevin without a prior hearing - the seller could take back the goods.

For Professor Sternlight, the relevant constitutional law from the Supreme Court seems to stop here. She notes that Fuentes is the last Supreme Court decision "directly addressing the waiver of constitutional rights in a civil context." 108

Fuentes, however, was "sharply curtailed" 109 only two years later by Mitchell $v$. W.T. Grant Co. ${ }^{110}$ The facts of Mitchell were almost identical to those of Fuentes - a debtor's default on a conditional sales contract. ${ }^{111}$ As in Fuentes, the state statute in Mitchell permitted the creditor, upon ex parte application and the posting of a bond, to obtain a writ instructing the sheriff or "constable" to take possession of the goods from the debtor. ${ }^{112}$ Nevertheless, the Mitchell Court rejected the debtor's argument that due process entitled him to a hearing before seizure of the goods. ${ }^{113}$ The Court distinguished Fuentes on the ground of differing statutes; the statute in Mitchell required the creditor's affidavit to allege specific facts and provided for the writ to be issued by a judge with discretion to deny it. ${ }^{114}$ In contrast, the statutes in Fuentes allowed the creditor's

104. Id. at 96.

105. Id. at 95 .

106. $I d$.

107. Id. at $95-96$.

108. Sternlight, Rethinking, supra note 40, at 54; see also Reuben, supra note 40, at 1020-21 ("Two cases, however, do provide a starting point on the substance of knowledge and voluntariness: D.H. Overmyer Co. v. Frick and Fuentes v. Shevin."). Professor Sternlight does acknowledge that "the Court's 1991 decision in Carnival Cruise Lines, Inc. v. Shute[, 499 U.S. 585 (1991),] also provides insight into how the Court would assess the constitutionality of an arbitration clause imposed by a company on weaker parties, such as consumers." Sternlight, Rethinking, supra note 40.

109. Shell, supra note 97 , at $477-78$.

110. 416 U.S. 600 (1974).

111. Id. at 601-02.

112. Id. at 621-23.

113. Id. at 607 .

114. Id. at 616 . 
affidavit to be conclusory and provided for the writ to be issued by a court clerk without judicial participation. ${ }^{115}$

Supporting Professor Sternlight's treatment of Fuentes as the last Supreme Court decision "directly addressing the waiver of constitutional rights in a civil context"116 is that Mitchell does not use the term "waiver" to describe the effect of the debtor's contract on his due process rights. Importantly, however, Mitchell treats the contract granting a lien as a waiver of the due process right to a predeprivation hearing:

Plainly enough, this is not a case where the property sequestered by the court is exclusively the property of the defendant debtor. The question is not whether a debtor's property may be seized by his creditors, pendente lite, where they hold no present interest in the property sought to be seized. The reality is that both seller and buyer had current, real interests in the property, and the definition of property rights is a matter of state law. Resolution of the due process question must take account not only of the interests of the buyer of the property but those of the seller as well. ${ }^{117}$

Thus, the Mitchell Court suggested that, had there been no contract granting a lien, the due process result would have been different. ${ }^{118}$ In other words, the contract granting the lien waived due process rights the debtor otherwise would have retained. And this was true even though the contract was a form contract presented take-it-or-leave-it to an unrepresented consumer. Mitchell treats a consumer's form contract as a waiver of the due process right to a predeprivation hearing. As Professor Richard G. Shell writes, Mitchell "put to rest any notion that contractual waivers of due process rights would always be governed by special default rules or limited to sophisticated parties. "119 Mitchell plainly does not require "knowing" consent; rather, it seems to use contract-law standards of consent.

In its most recent case on point, Connecticut $v$. Doehr, ${ }^{120}$ the Supreme Court continued its treatment of lien-granting contracts as waivers of due process rights. The Doehr plaintiff's claim was for assault and battery. ${ }^{121}$ Unlike the plaintiff-creditor in Mitchell, the plaintiff in Doehr had not obtained a contract granting him a lien. The Doehr Court repeatedly relied on this distinction in

115. Id. at 615-16.

116. Sternlight, Rethinking, supra note 40 , at 54 (emphasis added).

117. 416 U.S. at 604.

118. As a matter of policy, such a difference is quite defensible. As Professor Barry L. Zaretsky wrote:

Di-Chem, Mitchell, Fuentes, and Sniadach may be reconciled by considering the type of procedure involved in each. In a replevin proceeding, both the debtor and the creditor have an interest in the specific property. The debtor has a possessory interest and the creditor typically has a nonpossessory lien. In balancing these interests, a state may relax the debtor's due process rights and permit the creditor first to seize the property and then to litigate. In a garnishment or attachment situation, however, the creditor has no interest in the specific property, absent extraordinary circumstances.

Barry L. Zaretsky, Attachment Without Seizure: A Proposal for a New Creditors' Remedy, 1978 U. ILL. L.F. 819, 831 (citations omitted).

119. Shell, supra note 97 , at 477.

120. 501 U.S. 1 (1991).

121. Id. at 5 . 
holding that no predeprivation hearing was constitutionally required. ${ }^{122}$ Although Doehr, like Mitchell, does not use the word "waiver," it treats a liengranting contract as a waiver of the due process right to a predeprivation hearing.

Consistent with this reading of Fuentes, Mitchell, and Doehr, lower courts tend to hold that, in the absence of "exigent circumstances," due process requires a predeprivation hearing except when the plaintiff has obtained a predispute contract and lien. ${ }^{123}$ In effect, this exception treats contracts granting

122. Id. at 18. The Doehr Court held a Connecticut statute unconstitutional because it permitted the deprivation of property without due process. Id. at 8 . The deprivation, a prejudgment attachment of real estate, occurred without the defendant's receiving notice or the opportunity for a hearing. $I d$. at 15. The Court distinguished Mitchell on the ground that,

in Mitchell, the plaintiff had a vendor's lien to protect, the risk of error was minimal because the likelihood of recovery involved uncomplicated matters that lent themselves to documentary proof, and the plaintiff was required to put up a bond. None of these factors diminishing the need for a predeprivation hearing is present in this case. . .

Finally, we conclude that the interests in favor of an ex parte attachment, particularly the interests of the plaintiff, are too minimal to supply such a consideration here. The plaintiff had no existing interest in Doehr's real estate when he sought the attachment. His only interest in attaching the property was to ensure the availability of assets to satisfy his judgment if he prevailed on the merits of his action.

$\cdots$

... Attachments, moreover, were [at common law] generally confined to claims by creditors. As we and the Court of Appeals have noted, disputes between debtors and creditors more readily lend themselves to accurate ex parte assessments of the merits. Tort actions, like the assault and battery claim at issue here, do not.

Id. at 15-17 (citations omitted).

123. The best example of the distinction between plaintiff-creditors who have and have not obtained a predispute contract and lien may be Shaumyan v. O'Neill, 987 F.2d 122 (2d Cir. 1993). Shaumyan involved the same prejudgment attachment statute that Doehr held unconstitutional as applied in the context of an assault and battery case. Yet the Second Circuit held that the statute "is constitutional as applied to this debtor-creditor dispute." Id. at 123. The court distinguished Doehr on two grounds: First, Shaumyan involved a predispute contract. See id. at 126-27 (distinguishing an intentional tort case from the Shaumyan's refusing "to pay an outstanding sum certain due under their contract with Sidetex"). Second, Shaumyan involved a lien. See id. at 127-28 (distinguishing the Doehr plaintiff's lack of a preexisting interest in the defendant's property from the Shaumyan plaintiff's mechanic's lien). The Second Circuit held these two grounds were determinative under the second and third of the three factors in the Matthews v. Eldridge "balancing test" used by Doehr. See id. at 125 (citing Matthews v. Eldridge, 424 U.S. 319 (1976)). Those factors are the "risk of erroneous deprivation" and the "interest of the party seeking the prejudgment remedy." $I d$.

For other cases and commentators distinguishing between plaintiff-creditors who had obtained a predispute contract and lien and those who had not, see Union Trust Co. v. Heggelund, 594 A.2d 464, 466 n.3 (Conn. 1991) ("[T]his is not a tort suit, but a suit on a debt, and disputes between debtors and creditors more readily lend themselves to accurate ex parte assessments of the merits.") (quotations omitted); Shawmut Bank of R.I. v. Costello, 643 A.2d 194, 200 (R.I. 1994) (distinguishing Mitchell in part because the plaintiff in Mitchell had a predispute lien on the property to be seized); CHARLES Alan Wright \& ARThur R. Miller, 4 Federal PRACTICE AND Procedure $\$ 1074$ n.49 (2002) ("Although attempting to draw the line between Fuentes and Mitchell may be difficult, it appears that the Supreme Court in Mitchell went no further than to approve a preadversary hearing seizure of property in which the party obtaining the seizure had a clear and convincing interest, in that case a so-called seller's lien."); Linda Beale, Note, Connecticut v. Doehr and Procedural Due Process Values: The Siniadach Tetrad Revisited, 79 CORNELL L. REV. 1603, 1636 (1994) ("[E]ither a preexisting interest held by the attacher or one of the several exigent circumstances mentioned in the cases, plus some appropriate alternative safeguards set forth in Mitchell, would meet procedural due process requirements without need for a prejudgment hearing." ); see also Lewis Serv. Ctr., Inc. v. Mack Fin. Corp., 696 F.2d 66 
liens, such as security agreements governed by Article 9 of the Uniform Commercial Code, as waivers of the due process right to a predeprivation hearing.

Form security agreements are routinely enforced in consumer ${ }^{124}$ and other contexts. There is no constitutional requirement of knowing consent to a security agreement. Article 9 uses contract-law standards of consent, ${ }^{125}$ and courts routinely apply these standards to form security agreements even though such agreements seem to waive a constitutional due process right. ${ }^{126}$ In sum, the relevant doctrine after Overmyer, Fuentes, Mitchell, Doehr, and lower court cases applying them is that lien-granting contracts are waivers of constitutional rights and that such waivers are enforceable, even in the absence of knowing consent, so long as contract-law standards of consent are satisfied.

This doctrinal conclusion would not be reached by an analysis stopping with Overmyer and Fuentes, such as Professor Sternlight's "urg[ing] the Court to

(8th Cir. 1982) (holding an immediate post-seizure hearing sufficient to satisfy due process); Crown Builders, Inc. v. Stowe Eng'g Corp., 8 F. Supp. 2d 483 (D.V.I. 1998) (concluding due process required the court to construe the replevin statute to require a predeprivation hearing in a case in which the plaintiff lacked a predispute lien); Shawmut Bank v. Valley Farms, 610 A.2d 652, 657-58 (Conn. 1992) (holding that due process required the court to construe the replevin statute to require a predeprivation hearing even though the plaintiff had obtained a predispute security agreement); Gazil, Inc. v. Super Food Servs., Inc., 356 So. 2 d 312 (Fla. 1978).

Of course, due process can be violated even in the context of a plaintiff-creditor who has obtained a predispute contract and lien if the replevin statute lacks the procedural safeguards Mitchell requires. See, e.g., Wyatt v. Cole, 710 F. Supp. 180 (S.D. Miss. 1989); Thornton v. Carson, 533 P.2d 657 (Ariz. 1975). In other words, lien-granting contracts are waivers of some, but not all, due process rights.

124. The purchase-money security interest in consumers' automobiles is routine and has been for generations. In 1965, the primary drafter of Article 9 noted "that most automobile purchases are financed under some kind of security device," 1 GRANT GILMORE, SECURITY INTERESTS IN PERSONAL PROPERTY 550 (1965), and today a leading casebook on secured transactions says that "it seems probable that the number of security interests granted against automobiles in the United States each year exceeds the total number of security interests granted in all other types of personal property combined." LynN M. LoPucki \& ElizAbeth WARren, SECured Credit: A Systems ApProach 419 (4th ed. 2003).

125. Section 9-203 of the UCC states the requirements for the formation of an enforceable security agreement. See UCC § 9-203 (amended 2001). The only way in which this provision departs from general contract formation requirements is the requirement of a signed writing. This, of course, is "an evidentiary requirement in the nature of a Statute of Frauds." Id. cmt. 3. And there are many sorts of contracts within a Statute of Frauds, FARNSWORTH, supra note 16, § 6.2, including arbitration agreements, for which the FAA requires a writing. See 9 U.S.C. § 2 (2000).

126. See, e.g., Sonnier v. Boudreaux, 673 So. 2d 713, 717 (La. Ct. App. 1996) (rejecting a debtor's argument that "she did not realize she was signing a security agreement" on the grounds that "[a]lthough the law does not compel people to read or to inform themselves of the contents of instruments ... they may choose to sign, except in certain exceptional cases, it holds them to the consequences, in the same manner and to the same extent as though they had exercised those rights"); see also Michael M. Greenfield, The Role of Assent in Article 2 and Article 9, 75 WASH. U. L.Q. 289, 296 (1997) ("Article 9 poses no limitations on the types of goods in which a creditor may take a security interest and pays no special attention to the process by which a consumer apparently assents to the creation of a security interest in his or her assets."); Edward J. Janger, Predicting When the Uniform Law Process Will Fail: Article 9, Capture and the Race to the Bottom, 83 IOWA L. REV. 569, 612 (1998) ("[S]ecured consumer credit transactions are largely the result of contracts of adhesion. An automobile purchaser rarely negotiates the terms under which her car may be repossessed when she takes out a loan secured by the car. Even more problematic, many store credit cards create purchase money security interests with language on the back of the charge slip. In these instances, the consumer may not even be aware that a security interest has been created and perfected."). 
apply to arbitration agreements the civil waiver standard it has begun to develop in such cases as Fuentes and Overmyer." ${ }^{127}$ That this urging is based on a dated reading of constitutional law is demonstrated by Professor Shell's wideranging study of contract cases in the Supreme Court. Shell discusses three periods in the Court's treatment of contracts: "(1) the Lochner-era period from 1870 to 1937; (2) the New Deal/Warren Court from 1937 to 1971; and (3) the modern Court from 1971 to the present." ${ }^{128}$ Although "[s]cholars generally consider the Lochner era to be the high water mark for freedom of contract in Supreme Court history," ${ }^{129}$ Shell concludes "that the modern Court is, in important respects, more market-oriented than the Lochner Court." ${ }^{130}$ Interestingly, the cases Sternlight urges the Court to apply in the arbitration context, Fuentes and Overmyer, were decided at the transition point between the New Deal/Warren era and the modern era. Shell states that

\begin{abstract}
[a]lthough Fuentes was decided in 1972, one year after the cutoff point for the Warren Court era used in this Article, a four-Justice Warren Court coalition consisting of Justices Stewart, Douglas, Brennan, and Marshall issued the plurality opinion for the seven-member Court. Justices Powell and Rehnquist took no part in the decision, and Justices White, Blackmun, and Burger dissented. Fuentes therefore represents the last effort of the Warren Court Justices to stamp their views on contract into the Constitution. $^{131}$
\end{abstract}

In Mitchell, by contrast, "a voting majority consisting of Justices White, Powell, Burger, Blackmun, and Rehnquist sharply curtailed Fuentes v. Shevin." ${ }^{132}$ Justices Stewart, Douglas, Marshall, and Brennan dissented. ${ }^{133}$ As Professor Shell's study indicates, the Mitchell majority, rather than the Fuentes plurality, better represents the modern Court and, presumably, current standards of consent for the waiver of constitutional rights. For this reason, among others, courts should resist Professor Sternlight's urging that they apply pre-Mitchell standards to arbitration agreements. $^{134}$

\title{
C. Forum-Selection Clauses
}

Property-deprivation cases such as Mitchell are not the only ones in which constitutional rights are waived by form contract. Such waivers also occur

127. Sternlight, Rethinking, supra note 40 , at 57.

128. Shell, supra note 97 , at 447.

129. Id.

130. Id. at 437 .

131. Id. at $474 \mathrm{n} .244$.

132. Id. at 477-78.

133. Mitchell v. W.T. Grant Co., 416 U.S. 600, 629-36 (1974).

134. Professor Sternlight is not alone in wanting the Supreme Court to depart from its practice of applying contract-law standards of consent to constitutional rights. See Brunet, supra 40, at 108 (expressing dissatisfaction that "the present threshold for waiving civil constitutional rights seems to be that the waiving party only have satisfied contract law principles"); Linda S. Mullenix, Another Choice of Forum, Another Choice of Law: Consensual Adjudicatory Procedure in Federal Court, 57 FordHAM L. REV. 291, 365 (1988) (decrying the application of contract principles to determine whether a forumselection clause is an enforceable waiver because of the "ominous" implications for the surrender of constitutional rights); Rubin, supra note 68, at 545 (criticizing the use of contract law in determining whether a waiver of due process rights has occurred). 
through forum-selection clauses, contract clauses specifying the jurisdiction in which parties will litigate any disputes arising out of the contract. The landmark case is Carnival Cruise Lines, Inc. v. Shute ${ }^{135}$ in which the Supreme Court enforced a forum-selection clause in a form contract requiring the consumerplaintiffs, who were from Washington State, to sue in Florida. ${ }^{136}$ In enforcing this nonnegotiated clause contained in three pages of fine print, the Carnival Cruise Court applied contract-law standards of consent, rather than a knowingconsent standard. ${ }^{137}$ Furthermore, the Court endorsed a law-and-economics rationale for doing so, citing an opinion by Judge Richard Posner for the proposition that "it stands to reason that passengers who purchase tickets containing a forum clause like that at issue in this case benefit in the form of reduced fares reflecting the savings that the cruise line enjoys by limiting the fora in which it may be sued." 138

While Professor Sternlight concedes that Carnival Cruise "provides insight into how the Court would assess the constitutionality of an arbitration clause imposed by a company on weaker parties, such as consumers, ${ }^{139}$ she distinguishes the case on the ground that it "did not involve waiver of an accepted constitutional right, in that the Court has never found that plaintiffs have a constitutional right to sue in a convenient jurisdiction. ${ }^{140}$ This seems to be an open question. In Phillips Petroleum Co. v. Shutts, ${ }^{141}$ the Supreme Court said:

Because States place fewer burdens upon absent class plaintiffs than they do upon absent defendants in nonclass suits, the Due Process Clause need not and does not afford the former as much protection from state court jurisdiction as it does the latter. The Fourteenth Amendment does protect "persons," not "defendants," however, so absent plaintiffs as well as absent defendants are entitled to some protection from the jurisdiction of a forum State which seeks to adjudicate their claims. ${ }^{2}$

135. 499 U.S. 585 (1991). Carnival Cruise has since been overruled by Congress in the context of passenger tickets. 46 U.S.C. app. $§ 183$ c(a)(2) (2000). However, this ought not affect the discussion here because Carnival Cruise is referenced here only for its bearing on how the Supreme Court might react to arbitration clauses in light of its reaction to forum-selection clauses.

136. The clause provided:

It is agreed by and between the passenger and the Carrier that all disputes and matters whatsoever arising under, in connection with or incident to this Contract shall be litigated, if at all, in and before a Court located in the State of Florida, U.S.A., to the exclusion of the Courts of any other state or country.

499 U.S. at 587-88.

137. The Court did not "address the question whether respondents had sufficient notice of the forum clause before entering the contract for passage" because it found the plaintiffs "essentially have conceded that they had notice of the forum selection provision." Id. at 590 (citing Brief for Respondents 26 ("The respondents do not contest the incorporation of the provisions nor [sic ] that the forum selection clause was reasonably communicated to the respondents, as much as three pages of fine print can be communicated.").

138. Id. at 594 (citing Northwestern Nat'l Ins. Co. v. Donovan, 916 F.2d 372, 378 (7th Cir. 1990)). Professor Sternlight points out that "[m]any commentators have sharply attacked the Court for its blithe conclusion that the Carnival Cruise forum selection clause would benefit passengers as well as the cruise line." Sternlight, Rethinking, supra note 40, at 55.

139. Id. at 54 .

140. Id.

141. 472 U.S. 797 (1985).

142. Id. at 811 . 
While Professor Sternlight correctly notes that Shutts involved class actions in particular and did not announce a general "constitutional right to sue in a convenient jurisdiction," ${ }^{143}$ Shutts can be fairly read to say that plaintiffs have some due process "protection from the jurisdiction of a forum State which seeks to adjudicate their claims. ${ }^{144}$ Thus, it is at least plausible that a forum-selection clause like that in Carnival Cruise waives consumer-plaintiffs' due process rights.

Even if the rights waived by forum-selection clauses do not include due process rights, they sometimes include the Seventh Amendment jury-trial right. Carnival Cruise apparently did not involve such a waiver because, first, the Seventh Amendment applies in both the contractually selected forum and the forum that otherwise would have heard the case, and, second, Carnival Cruise is an admiralty case, and there is no Seventh Amendment jury-trial right in admiralty cases. ${ }^{145}$ Other forum-selection cases, however, do involve waiver of the Seventh Amendment jury-trial right. ${ }^{146}$ These are cases in which that right is present in the forum that would have heard the case but not in the forum selected in the contract. The most common examples are cases in which the selected forum is outside the United States. In several such cases, federal courts have enforced a clause selecting a non-U.S. forum in which there is no jury-trial

143. Sternlight, Rethinking, supra note 40, at 54.

144. See Edward A. Purcell, Jr., Geography As a Litigation Weapon: Consumers, Forum-Selection Clauses, and the Rehnquist Court, 40 UCLA L. REV. 423, 465 (1992) ("In cases like Carnival Cruise consumer-plaintiffs should receive the full protection that the Due Process Clause guarantees for a simple but compelling reason: the function of forum selection clauses in consumer form contracts is precisely to reverse the standard position of the parties with respect to forum selection.").

145. The Propeller Genesee Chief v. Fitzhugh, 53 U.S. (12 How.) 443, 459-60 (1851) (upholding the constitutionality of a statute providing for the right to jury trial in admiralty proceedings); Waring $\mathrm{v}$. Clarke, 46 U.S. (5 How.) 441, 460 (1847) (holding that the Seventh Amendment does not require jury trials in admiralty cases).

However, if the plaintiff can show an additional ground for federal jurisdiction, then the plaintiff does have a Seventh Amendment jury-trial right, at least if the plaintiff forgoes admiralty jurisdiction and procedures in favor of the "law" side of the court under the other ground for federal jurisdiction. See, e.g., Ghotra by Ghotra v. Bandila Shipping, Inc., 113 F.3d 1050, 1057 (9th Cir. 1997); Linton v. Great Lakes Dredge \& Dock Co., 964 F.2d 1480, 1489 (5th Cir. 1992); CHARLES Alan WRIGHT ET. AL, 14A Federal PRACTICE AND PROCEDURE $\$ 3672$ (3d ed. 1998) ("A claim brought on the 'law' side of the federal courts can be tried to a jury on demand of one of the parties, even though it is maritime in nature, in accordance with the constitutional command of the Seventh Amendment."); David W. Robertson \& Michael F. Sturley, The Right to a Jury Trial in Jones Act Cases: Choosing the Forum Versus Choosing the Procedure, 30 J. MAR. L. \& COM. 649, 654 (1999). Accordingly, two diversity cases hold that passengers retain their jury-trial right in negligence actions against cruise lines. See McDonough v. Celebrity Cruises, Inc., No. 98 CIV. 1517(RWS), 2000 WL 341115, at *1 (S.D.N.Y. Mar. 30, 2000); Sullivan v. Ajax Navigation Corp., 881 F. Supp. 906, 910 (S.D.N.Y. 1995). These cases do not explicitly state whether the plaintiffs' jury-trial rights are constitutional or merely statutory.

146. It is, therefore, overbroad to say that forum-selection clauses do not waive a constitutional right. See, e.g., Heller Fin., Inc. v. Finch-Bayless Equip. Co., No. 90 C 1672, 1990 WL 103232, at *1 (N.D. Ill. July 17, 1990) ("Unlike the right to a jury trial, contractual forum selection impairs no constitutional rights unless the forum selected denies a party due process. The Bremen v. Zapata Off-Shore Co., 407 U.S. 1, 15 (1972). For a contractual waiver of constitutional rights to be effective, it must be knowingly and voluntarily signed."); Hydramar, Inc. v. Gen. Dynamics Corp., No. CIV. A. 85-1788, 1989 WL 159267, at $* 2$ n.5 (E.D. Pa. Dec. 29, 1989) (stating that a forum-selection clause "is clearly distinguishable from a Seventh Amendment demand for a jury trial matter and involves significantly less profound interest."). 
right even though the claims appear to have been legal, rather than equitable, and thus, entitled to a jury trial under the Seventh Amendment. ${ }^{147}$ In enforcing these clauses, these cases enforce the waiver of the Seventh Amendment jurytrial right.

These cases appear to use contract-law standards of consent, rather than a knowing-consent standard. ${ }^{148}$ Many cite and apply The Bremen v. Zapata OffShore Co. ${ }^{149}$ in which the Court held that the forum-selection clause at issue should have been enforced "unless Zapata could clearly show that enforcement would be unreasonable and unjust, or that the clause was invalid for such reasons as fraud or overreaching." 150 Though Bremen was an admiralty case in which Seventh Amendment was apparently not implicated, federal courts have applied this standard to forum-selection clauses that did waive the jury-trial right. For example, in a breach of contract action, the Ninth Circuit said:

The enforceability of forum selection clauses in international agreements is controlled by the Supreme Court's decision in The Bremen v. Zapata Off-Shore Co. In Bremen, the Court first held that forum selection clauses are prima facie valid and should not

147. See Interamerican Trade Corp. v. Companhia Fabricadora De Pecas, 973 F.2d 487 (6th Cir. 1992) (breach of contract claim; Brazilian courts selected); Paper Express, Ltd. v. Pfankuch Maschinen, 972 F.2d 753 (7th Cir. 1992) (breach of warranty claim; German courts selected); Spradlin v. Lear Siegler Mgt. Servs. Co., Inc., 926 F.2d 865 (9th Cir. 1991) (claims for breach of contract, slander, emotional distress, fraud, and age discrimination; Saudi Arabian courts selected); Taag Linhas Aereas de Angola v. Transamerica Airlines, Inc., 915 F.2d 1351 (9th Cir. 1990) (breach of contract claim; Swiss courts selected); Appell v. George Philip \& Son, Ltd., 760 F. Supp. 167 (D. Nev. 1991) (breach of contract claim; English courts selected).

Federal appellate courts are unanimous in enforcing forum-selection clauses with respect to securities fraud claims brought by U.S. investors or "Names" in Lloyd's of London. See, e.g., Lipcon v. Underwriters of Lloyd's London, 148 F.3d 1285 (11th Cir. 1998); Richards v. Lloyd's of London, 135 F.3d 1289 (9th Cir. 1998) (en banc). These cases enforce clauses choosing the courts of England, even though English courts do not use juries for claims like securities fraud, which are legal, rather than equitable, and thus within the Seventh Amendment. In most of the Lloyd's cases, however, the investors traveled to London to execute the contracts. See, e.g., Lipcon, 148 F.3d at 1288. Thus, consent was probably "knowing."

148. Even cases refusing to enforce international forum-selection clauses seem to use contract-law standards of consent, rather than knowing consent. See, e.g., Sun Trust Bank v. Sun Int'l Hotels, Ltd., 184 F. Supp. 2d 1246 (S.D. Fla. 2001). Sun Trust involved a forum-selection clause on a guest registration form at a Bahamian resort. The court refused to enforce the clause on grounds that might best be called procedural unconscionability:

It is further undisputed that the forum-selection clause was presented to her for the first time upon arrival in the Bahamas, after she had flown there with her two children. Moreover, the manner in which the forum-selection clause is presented to the guest makes it objectively appear to be a required part of the registration process. The guest is told to read and sign, not to read and then decide if they want to sign. This may explain why defendants are not aware of anyone ever refusing to sign the clause; no reasonable person in Ms. Humphreys' [sic] position would think they had such an option.

Id. at 1261. The Sun Trust court rejected the plaintiff's argument that the clause should be unenforceable because she did not give knowing consent: "Ms. Humphreys did not realize that she was signing a restrictive clause because she did not read it before signing, not because it was hidden from her." Id. at 1260; see also Doe v. Sun Int'l Hotels, Ltd., 20 F. Supp. 2d 1328, 1331 (S.D. Fla. 1998) (holding, when an eighteen-year-old plaintiff alleged that she was raped while on vacation at the defendant's resort, that her stepfather's signature on a guest registration form containing a forum-selection clause "was either insufficient to bind her or was voided . . . upon [her] reaching the age of majority").

149. 407 U.S. 1 (1972).

150. Id. at 15 . 
be set aside unless the party challenging enforcement of such a provision can show it is

"'unreasonable' under the circumstances." The Supreme Court has construed this exception narrowly. A forum selection clause is unreasonable if (1) its incorporation into the contract was the result of fraud, undue influence, or overweening bargaining power; (2) the selected forum is so "gravely difficult and inconvenient" that the complaining party will "for all practical purposes be deprived of its day in court,"; or (3) enforcement of the clause would contravene a strong public policy of the forum in which the suit is brought. To establish the unreasonableness of a forum selection clause, Appellants have the "heavy burden of showing that trial in the chosen forum would be so difficult and inconvenient that the party would effectively be denied a meaningful day in court."

Although Bremen is an admiralty case, its standard has been widely applied to forum selection clauses in general. ${ }^{151}$

Nowhere in this statement of law is there a requirement of knowing consent. In fact, this sounds very much like a statement of ordinary contract law-including the doctrines of misrepresentation, undue influence, unconscionability, and illegality-as applied to forum-selection clauses.

Likewise, in Leonard v. Garantia Banking Ltd., ${ }^{152}$ the Second Circuit affirmed a decision citing Bremen in rejecting knowing-consent standards in favor of contract-law standards of consent. Importantly, the court in Leonard enforced a Bahamian forum-selection clause despite the agreement's having been written in English and the plaintiff-investor's lack of fluency in English. The Leonard court reasoned, "There is no indication that [the defendant] did anything to prevent [the plaintiff] from having the Agreement translated before signing it." 153

In Spradlin v. Lear Siegler Management Services Co. ${ }^{154}$ the Ninth Circuit enforced a forum-selection clause waiving the jury-trial right even though the clause was in an employment agreement and even though the chosen forum was Saudi Arabia, a nation whose laws hardly resemble those of the United States. ${ }^{155}$ The Spradlin court cited Bremen and said:

There is nothing in the case law ... to suggest that a different analysis applies to forum selection clauses in employment contracts than generally applies to commercial contracts.

On the contrary, while there are few published opinions addressing the issue in the employment context, those opinions all apply the framework set out in Bremen and its progeny. ${ }^{156}$

151. Argueta v. Banco Mexicano, S.A., 87 F.3d 320, 324-25 (9th Cir. 1996) (citations omitted).

152. No. CIV.A.85-1788, 1999 WL 944802, at *6 (S.D.N.Y. Oct. 19, 1999), aff'd, 213 F.3d 626 (2d Cir. 2000).

153. $I d$. at $* 7-8$.

154. 926 F.2d 865 (9th Cir. 1991).

155. Id. at 866. ("This Employment Agreement shall be governed by the laws of the Kingdom of Saudi Arabia. The courts of Saudi Arabia shall have sole jurisdiction over any disputes arising out of this Employment Agreement."). The case involved claims for breach of contract, slander, emotional distress, fraud, and age discrimination.

156. Id. at 867. The Spradlin court cited cases enforcing forum-selection clauses in employment agreements selecting the courts of Saudi Arabia and West Germany as the forum, as well as an employment arbitration agreement selecting France. See id. (citing Tisdale v. Shell Oil Co., 723 F. Supp. 653, 654-57 (M.D. Ala. 1987) (Saudi Arabia); Gaskin v. Stumm Handel GmbH, 390 F. Supp. 361, 
In sum, courts are applying Bremen's standards of consent to a variety of forumselection clauses that waive the Seventh Amendment jury-trial right, and these standards are far closer to contract-law standards than knowing-consent standards. While most of these cases involve businesses, a few involve individual employees and investors. And federal courts have even used Bremen-Carnival Cruise standards to enforce international forum-selection clauses in the context of consumer cruise tickets. ${ }^{157}$ The plaintiffs in these cruise cases likely would have had a Seventh Amendment jury-trial right had the clauses not been enforced because the plaintiffs likely could have satisfied diversity, as well as admiralty, jurisdiction. ${ }^{158}$

There is, then, in the law governing forum-selection clauses, ample precedent to support the constitutionality of the FAA's contract-law standards of consent. While arbitration agreements waive the Seventh Amendment jurytrial right, so do many international forum-selection clauses. And the cases on international forum-selection clauses, including Bremen, use consent standards far closer to those of contract law than to a knowing-consent standard.

It must be conceded, however, that the courts enforcing international forum-selection clauses do not acknowledge that by holding such clauses enforceable they are holding that a party has waived a constitutional right. Few international forum-selection clause cases even mention the absence of a jury in the contractually chosen forum, and none of those that do say, "Wait! That's important! That means a constitutional right is involved here, so we better think long and hard about the applicable standards of consent for waiver!" While Professor Sternlight points out that arbitration cases generally evince a "lack of attention" to the fact that arbitration clauses waive constitutional jurytrial rights, ${ }^{159}$ international forum-selection cases seem to pay no attention to the issue at all.

\section{Consent-to-Jurisdiction Clauses}

Forum-selection clauses can be used to compel a defendant to litigate in the contractually chosen forum even though that forum would not have had jurisdiction over that defendant in the absence of the clause. In this context, the

366-70 (S.D.N.Y. 1975) (West Germany); Pauly v. Biotronik, GmbH, 738 F. Supp. 1332, 1334-35 (D. Or. 1990) (France)).

157. Effron v. Sun Line Cruises, Inc., 67 F.3d 7 (2d Cir. 1995); Hodes v. S.N.C. Achille Lauro ed Altri-Gestione, 858 F.2d 905 (3d Cir. 1988), over'd on other grounds, 490 U.S. 495 (1989); Hollander v. K-Lines Hellenic Cruises, S.A., 670 F. Supp. 563 (S.D.N.Y. 1987). But see Schaff v. Sun Line Cruises, Inc., 999 F. Supp. 924 (S.D. Tex. 1998) (denying Sun Cruise Line's motion to dismiss because Schaff received the ticket containing the forum-selection clause after her purchase and would thus have to forfeit the purchase price if she rejected the cruise contract). In Effron, the Second Circuit relied on a Supreme Court arbitration decision in holding that "[t]he fact that Sun Line Greece's Passage contract designates a foreign court as the forum for adjudication does not change the inconvenience calculus" of Bremen. 67 F.3d at 10 (citing Vimar Seguros y Reaseguros, S.A. v. M/V Sky Reefer, 515 U.S. 528 (1995)).

158. See supra note 145.

159. Sternlight, supra note Error! Bookmark not defined., at 711-16. 
clause, often called a "consent-to-jurisdiction" or "submission-to-jurisdiction" clause, indisputably waives constitutional rights. The Supreme Court held in International Shoe Co. v. Washington ${ }^{160}$ that due process requires "that in order to subject a defendant to a judgment in personam, if he be not present within the territory of the forum, he have certain minimum contacts with it such that the maintenance of the suit does not offend 'traditional notions of fair play and substantial justice.' "161 But, as Professor Shell explains, in Burger King Corp. v. Rudzewicz, ${ }^{162}$ the Court "signaled its acceptance of standardized contracts as a means of waiving the due process rights embodied in the 'minimum contacts' limits of personal jurisdiction." 163 The Burger King Court said:

We have noted that, because the personal jurisdiction requirement is a waivable right, there are a "variety of legal arrangements" by which a litigant may give "express or implied consent to the personal jurisdiction of the court." For example, particularly in the commercial context, parties frequently stipulate in advance to submit their controversies for resolution within a particular jurisdiction. Where such forum selection provisions have been obtained through "freely negotiated" agreements and are not "unreasonable and unjust," [citing Bremen], their enforcement does not offend due process. ${ }^{164}$

While this language is largely dicta because Burger King did not involve a consent-to-jurisdiction clause, it did signal an endorsement of such clauses. Since Burger King, many courts have enforced consent-to-jurisdiction clauses that waive constitutional rights - that is, clauses that require a defendant to litigate in a forum that otherwise would not have had jurisdiction over that defendant. ${ }^{165}$

160. 326 U.S. 310 (1945).

161. Id. at 316 (quoting Milliken v. Meyer, 311 U.S. 457, 463 (1940)).

162. 471 U.S. 462 (1985).

163. Shell, supra note 97, at 478 ("In Burger King Corp. v. Rudzewicz, the Court declared that a choice of law clause contained in the boilerplate language of a franchise agreement, combined with the proposed twenty-year business relationship contemplated by the agreement, was persuasive evidence that a party had consented to be sued in the forum whose law had been selected.").

164.Burger King, 471 U.S. at 473 n.14. (citations omitted); see Nat'l Equip. Rental, Ltd. v. Szukhent, 375 U.S. 311, 320 (1964) (permitting New York jurisdiction over Michigan defendants who signed a form contract appointing a New York agent to receive service of process, over a dissent stating that "upholding service of process in this case raises serious questions as to whether these Michigan farmers have been denied due process of law in violation of the Fifth and Fourteenth Amendments").

165. See, e.g., Rooney v. Biomet, Inc., No. 99-2160, 2000 WL 559224 (1st Cir. Apr. 13, 2000); Gateway, Inc. v. Vitech Am., Inc., 143 F. Supp. 2d 391, 396 (S.D.N.Y. 2001) ("The terms of the contract plainly establish that Microtec [a Brazilian corporation] has waived any objection to the exercise of personal jurisdiction by this Court."); Hanson Eng'rs Inc. v. UNECO, Inc., 64 F. Supp. 2d 797, 800 (C.D. Ill. 1999); Res. Ventures, Inc. v. Res. Mgmt. Intl., Inc., 42 F. Supp. 2d 423, 431 (D. Del. 1999) (stating that personal jurisdiction "can be waived by a party's express or implied consent to jurisdiction [and that the] use of a forum selection clause is an example of an express consent to personal jurisdiction") (citations omitted); Danka Funding, L.L.C. v. Page, Scrantom, Sprouse, Tucker \& Ford, P.C., 21 F. Supp. 2d 465, 469 (D.N.J. 1998); Mut. Fire, Marine, \& Inland Ins. Co. v. Armour, No. CIV.A.86-3562, 1987 WL 9658, at *1 (E.D. Pa. Apr. 16, 1987); Richardson Greenshields Sec., Inc. v. Metz, 566 F. Supp. 131, 133 (S.D.N.Y. 1983); Leasecomm Corp. v. Crockett, No. 9456, 1998 WL 15935, at *2 (Mass. App. Div. Jan. 13, 1998) ("In the absence of contacts constitutionally sufficient to subject Crockett to long arm jurisdiction, Leasecomm could maintain an action against her in this Commonwealth only if Crockett contractually consented to Massachusetts jurisdiction through a forum selection clause. Massachusetts recognizes that such clauses are valid as the sole basis for jurisdiction over a nonresident and should be enforced unless it is demonstrably unfair or unreasonable to do so."); Nat'l Union Fire Ins. Co. of Pittsburgh, Pa. v. Worley, 690 N.Y.S.2d 57, 59 (App. Div. 1999) ("[B]y agreeing to the forum 
These cases reason that "[c]onsent to suit in a particular forum is an independent ground for the exercise of personal jurisdiction, separate and distinct from any personal jurisdiction based on an analysis of minimum contacts." 166

These cases generally appear to use contract-law standards of consent rather than a knowing-consent standard. Some explicitly reject knowing-consent standards. ${ }^{167}$ Some cases refusing to enforce consent-to-jurisdiction clauses even seem to use contract-law standards of consent. ${ }^{168}$ An example is Central Ohio Graphics, Inc. v. Alco Capital Resource, Inc. ${ }^{169}$ which (like many consent-tojurisdiction cases) arose out of an equipment lease. In Central Ohio, the Georgia Court of Appeals recognized that "[g]enerally, contractual clauses providing

selection clause in the indemnity agreement, defendant specifically consented to personal jurisdiction over her in the courts of New York and thereby waived any basis to dispute New York's jurisdiction."); Retail Investors, Inc. v. Henzlik Inv. Co., 439 S.E.2d 196, 198 (N.C. Ct. App. 1994) ("One method of consenting to personal jurisdiction is the inclusion in a contract of a consent to jurisdiction provision. This type of provision does not violate the Due Process Clause and is valid and enforceable unless it is the product of fraud or unequal bargaining power or unless enforcement of the provision would be unfair or unreasonable."); Sec. Credit Leasing, Inc. v. Armaly, 529 S.E.2d 283 (S.C. Ct. App. 2000); see also Fairfield Lease Corp. v. Romano's Auto Serv., 495 A.2d 286, 288 (Conn. App. Ct. 1985) (holding that "parties may agree 'to submit to the jurisdiction of a given court' "); Minuteman Press Int'l, Inc. v. Hoffman, 826 S.W.2d 34, 37 (Mo. Ct. App. 1992) ("The contacts of the Hoffmans with the forum state of New York in connection with subject matter of the litigation, supported by the forum selection clause in the licensing agreement, were sufficient to bring the Hoffmans within the jurisdiction of the New York court."); Chase Third Century Leasing Co. v. Williams, 782 S.W.2d 408 (Mo. Ct. App. 1989); Minuteman Press Int'l, Inc. v. Sparks, 782 S.W.2d 339 (Tex. Ct. App. 1989). But see Churchill Corp. v. Third Century, Inc., 578 A.2d 532, 536 (Pa. Super. Ct. 1990) ("Enforcement of forum selection under these leases would offend notions of due process ... and is therefore per se unreasonable.").

166. Hanson Eng'rs, 64 F. Supp. 2d at 800; see also Danka Funding, 21 F. Supp. 2d at 469 (finding jurisdiction after stating: "Because there is no question that defendant lacks the minimum contacts necessary to confer personal jurisdiction on this Court as contemplated by [International Shoe] and its progeny, the issue of whether personal jurisdiction exists rests solely on the enforceability of the forum selection clause in question.").

167. See, e.g., Sec. Credit Leasing, 529 S.E.2d at 286 ("Armaly merely alleged ... that he did not read the lease provisions. He had an opportunity to read the lease agreement and discover its contents, and is charged with notice of the content of the contract he signed."). But see Bell Atl. Tricon Leasing Corp. v. Johnnie's Garbage Serv., Inc., 439 S.E.2d 221, 224 (N.C. Ct. App. 1994) ("[W]e find that defendant did not knowingly and intelligently consent to the jurisdiction of the New Jersey courts. Therefore, enforcement of this provision would be both unfair and unreasonable.").

Some other courts that refuse to enforce consent-to-jurisdiction clauses do so on grounds found in state law rather than on the federal ground that the constitutional rights consent standard was not met. For example, Florida is among the minority of states requiring that defendants who have signed forumselection clauses also be reachable by the state's long arm statute. See, e.g., Johns v. Taramita, 132 F. Supp. 2d 1021, 1029 (S.D. Fla. 2001) ("[B]ecause there was no basis for jurisdiction under the state's long-arm statute, [this court] did not have personal jurisdiction over a nonresident defendant who had agreed to a Florida forum selection clause."); see also Ex parte Kenco Signs \& Awning Div., Inc., 732 So. 2d 1019, 1024 (Ala. Ct. App. 1999) ("[A] forum selection clause, however, cannot operate as the sole basis for a Florida court to exercise in personam jurisdiction over CDC.") (applying Florida law and citing McRae v. J.D./M.D., Inc., 511 So. 2d 540 (Fla. 1987)).

168. See, e.g., Cent. Ohio Graphics, Inc. v. Alco Capital Res., Inc., 472 S.E.2d 2 (Ga. Ct. App. 1996) (refusing to enforce an equipment lease because it "provides no intimation of the forum contemplated" and "as written would permit [the lessor] to bring this action in any state in the country" despite recognizing that "[g]enerally, contractual clauses providing advance consent to the jurisdiction of a court which would not otherwise have personal jurisdiction are valid and enforceable").

169.472 S.E.2d 2 (Ga. Ct. App. 1996). 
advance consent to the jurisdiction of a court which would not otherwise have personal jurisdiction are valid and enforceable." ${ }^{170}$ Nevertheless, the court refused to enforce the clause in that case because it "provides no intimation of the forum contemplated" and "as written would permit [the lessor] to bring this action in any state in the country." ${ }^{171}$ The reasoning and holding of Central Ohio are consistent with the contract-law standards of consent courts apply to arbitration clauses in form contracts. For example, courts have held unconscionable clauses requiring arbitration far from the location of the nondrafting party. $^{172}$

In support of the proposition that cases enforcing consent-to-jurisdiction clauses are using contract-law standards of consent is that many of these cases cite the Supreme Court's opinion in Bremen and derive from it a standard such as this:

[A] forum selection clause is presumptively valid and enforceable by the forum unless the objecting party establishes (1) that it is the result of fraud or overreaching, (2) that enforcement would violate a strong policy of the forum, or (3) that enforcement would in the particular circumstances of the case result in litigation in a jurisdiction so seriously inconvenient as to be unreasonable. ${ }^{173}$

This statement implies no requirement of knowing consent. In fact, this sounds very much like a statement of ordinary contract law as applied to consent-to-jurisdiction clauses. Some cases enforcing consent-to-jurisdiction clauses even cite Carnival Cruise and its law-and-economics rationale for using contract-law standards of consent. ${ }^{174}$ In short, courts do not seem to hold consent-to-jurisdiction clauses to a higher standard of consent than other forum-selection clauses.

170. Id. at 3 .

171. Id. at 4 .

172. See, e.g., Patterson v. ITT Consumer Fin. Corp., 18 Cal. Rptr. 2d 563, 566-67 (Cal. Ct. App.) ("While arbitration per se may be within the reasonable expectation of most consumers, it is much more difficult to believe that arbitration in Minnesota would be within the reasonable expectation of California consumers."), appeal denied, 1993 Cal. LEXIS 4322 (Cal. Aug. 12, 1993); Philyaw v. Platinum Enters., Inc., No. CL00-236, 2001 WL 112107, at *3 (Va. Cir. Ct. 2001) (holding an arbitration clause unconscionable because "[c]ommon sense dictates that retail purchasers such as the Philyaws could not afford the time and expense to go to Los Angeles to arbitrate a claim arising from a used car sale in Virginia").

173. Res. Ventures, Inc. v. Res. Mgmt. Int'l, Inc., 42 F. Supp. 2d 423, 431-32 (D. Del. 1999). Other consent-to-jurisdiction cases citing Bremen include Danka Funding, L.L.C. v. Page, Scrantom, Sprouse, Tucker \& Ford, P.C., 21 F. Supp. 2d 465, $469-70$ (D.N.J. 1998), and Inso Corp. v. Dekotec Handelsges, mbH, 999 F. Supp. 165, 166 (D. Mass. 1998 ) ("A party to a contract may waive its right to challenge personal jurisdiction by consenting to personal jurisdiction in a forum selection clause.").

174. See, e.g., Danka Funding, 21 F. Supp. 2d at 471 ("Despite defendant's arguments to the contrary, defendant can be presumed to have received appropriate consideration ... in the form of a lower price.") (citing Carnival Cruise Lines, Inc. v. Shutes, 499 U.S. 585 (1991)) (quotations omitted); see also Intermountain Sys., Inc. v. Edsall Const. Co., Inc., 575 F. Supp. 1195, 1197-98 (D. Colo. 1983) ("Whether Mr. Edsall discussed or specifically bargained about the venue provision is of little import. He is presumed to have received appropriate consideration, in the form of a lower price, for the venue selection clause."). 
Although most of the cases enforcing consent-to-jurisdiction clauses involve businesses, a few involve individual employees. ${ }^{175}$ And, as noted above, it does not take a consumer case to raise an inconsistency between contract-law standards of consent and constitutional requirements. If the Due Process Clause does require knowing consent, then this requirement has frequently gone unmet in consent-to-jurisdiction cases between businesses. Again, business people, like consumers, routinely sign form contracts without reading them, so it is simply not true that the line between business and consumer parties is the line between knowing and unknowing consent. ${ }^{176}$

Consent-to-jurisdiction cases seem to use contract-law standards of consent, but, like those considering forum-selection clauses, none acknowledges that by holding these contract clauses enforceable they are holding that a party has waived a constitutional right. Yet scholars critical of these cases note that this is exactly what these cases have done. Professor Linda Mullenix, for example, laments that these cases depart from the "longstanding American tradition that 'waivers of constitutional rights ... must be deliberately and understandingly made.' "177

In sum, contract-law standards are generally used for the waiver of constitutional rights in property-deprivation cases, forum-selection cases, and consentto-jurisdiction cases, as well as in arbitration cases. Case law governing jurywaiver clauses stands out because of its failure to apply contract-law standards of consent and its requirement that consent be "knowing." Part VI provides a history of jury-waiver clauses showing that the adoption of this requirement is both relatively recent and vulnerable to criticism.

175. See BABN Techs. Corp. v. Bruno, 25 F. Supp. 2d 593, 596 (E.D. Pa. 1998) ("[T]he mere fact that Bruno signed a form contract and did not negotiate the forum selection clause is not sufficient to render the clause unenforceable."); Phone Directories Co. v. Henderson, 8 P.3d 256, 261-62 (Utah 2000) (holding in an employment case that "people can contractually agree to submit to the jurisdiction of a particular court, even if that court might not have independent personal jurisdiction over them" because "the traditional defenses allowing one to avoid an unfair or unreasonable contract, such as duress and fraud, are available to parties litigating the validity of a forum").

176. See supra note 77 and accompanying text.

177. Mullenix, supra note 134 , at 369 . Mullenix contends,

It is ironic that the law steadfastly protects a defendant from litigation in an unreasonable forum when that defendant knows nothing at all about subject matter or personal jurisdiction, yet the law does not supply the same due process protection if the defendant signs a boilerplate agreement. In the latter instance the law simply imputes knowledge.

Id. at 367 .

It should be noted that Mullenix's criticism of the standards of consent applied to forum-selection clauses and consent-to-jurisdiction clauses is remarkably similar to Sternlight's criticism of arbitration law's standards of consent. That commentators who favor the higher knowing-consent standards are dissatisfied, for the same reasons, with many different areas of law only supports the proposition that contract-law standards of consent are found throughout many areas of law governing waiver of constitutional rights. 


\section{VI}

\section{THE OUTLIER: CASE LAW GOVERNING JURY-WAIVER CLAUSES}

This Article's examination of the law governing arbitration agreements, property-deprivation cases, forum-selection clauses, and consent-to-jurisdiction clauses suggests that contract-law standards of consent are at least as common as knowing-consent standards in the law governing civil waivers of constitutional rights. Professor Sternlight argues, however, that a knowing-consent standard is constitutionally required for arbitration agreements and, as support, cites case law applying knowing-consent standards to jury-waiver clauses. ${ }^{178}$ This may have it reversed. If the law governing jury-waiver clauses is the only major body of law regularly applying knowing-consent standards to civil waivers of constitutional rights, then perhaps $i t$ is the area of law that should change. Rather than arbitration law conforming to jury-waiver cases, perhaps jurywaiver cases should conform to arbitration law-and property-deprivation cases and forum-selection cases and consent-to-jurisdiction cases. Perhaps courts should stop requiring "knowing" consent in jury-waiver cases. This view is supported by many decades of case law in which courts applied contract-law standards of consent to jury-waiver clauses. It was not until the 1970s that courts imported the knowing-consent standard from criminal law into the civil context of the jury-waiver clause. These recent jury-waiver cases fell out of step with the other areas of law pertaining to civil waivers of constitutional rights.

\section{A. The Early History of the Case Law Governing Jury-Waiver Clauses}

The earliest reported case concerning a jury-waiver clause appears to have been decided in $1925 .{ }^{179}$ From 1925 through 1960, the vast majority of the cases involving jury-waiver clauses arose out of real property leases,${ }^{180}$ and most were decided by New York courts. ${ }^{181}$ In 1950, one of these courts noted that a particular form lease with a jury-waiver clause "is in very general use, being the form adopted by the real estate board. ${ }^{182}$ New York was not alone, though; a 1959 Ohio case involving a lease jury-waiver clause said such clauses "are common in Ohio. ${ }^{1183}$

In the 1925 case, Zeesell Realty Co. v. Cunningham, the New York Supreme Court, Appellate Term, refused to enforce a jury-waiver clause found in the

178. Sternlight, supra note Error! Bookmark not defined., passim.

179. See W.E. Shipley, Annotation, Validity and Effect of Contractual Waiver of Trial by Jury, 73 A.L.R.2d 1332, 1336 (1960) (citing Zeesell Realty Co. v. Cunningham, 211 N.Y.S. 591 (App. Term. 1925)). Research revealed no earlier cases involving predispute contracts with jury-waiver clauses. In 1874, however, the Supreme Court stated in dicta that a jury-waiver clause would be unenforceable. See Ins. Co. v. Morse., 87 U.S. (20 Wall.) 445 (1874) (refusing to enforce the parties' agreement not to remove the dispute to federal court).

180. Shipley, supra note 179.

181. Id. at 1334-35.

182. Caplan v. Goldman, 95 N.Y.S.2d 835, 837 (App. Term. 1950).

183. Union Commerce Bank v. Kimbro, 162 N.E.2d 926, 927 (Ohio Mun. Ct. 1959). 
eighteenth paragraph of a lease. ${ }^{184}$ This holding was reversed, however, by a higher court, the New York Supreme Court, Appellate Division. ${ }^{185}$ The Appellate Division reiterated its enforcement of jury-waiver clauses in a 1931 case also arising out of a lease, Waterside Holding Corp. v. Lask. ${ }^{186}$ Lask was then cited in 1934 and 1938 in two more New York cases enforcing jury-waiver clauses in leases. ${ }^{187}$ Lask was also cited by courts in Connecticut and Ohio enforcing lease jury-waiver clauses. ${ }^{188}$ The first federal case to rule on the enforceability of jury-waiver clauses (decided in 1941) likewise cited and followed Lask. ${ }^{189}$ More than a dozen other New York cases from the 1930s, 40s, and 50s also enforced lease jury-waiver clauses. ${ }^{190}$ In addition, at least two cases involved jury-waiver clauses in contracts other than leases. ${ }^{191}$ One of these was a "consumer" case insofar as it arose out of the purchase of an automobile. ${ }^{192}$ None of these cases suggested that anything other than contract-law standards of consent were being applied, and none suggested that enforceability depended on "knowing" consent or the like. Cases from this era that did refuse to enforce jury-waiver clauses did so, not because of a failure to meet a knowing-consent

184. 211 N.Y.S. 591 (App. Term. 1925).

185. See Waterside Holding Corp. v. Lask, 253 N.Y.S. 183, 184 (App. Div. 1931) (citing Zeesell

Realty Co. v. Cunningham, 213 N.Y.S. 942 (App. Div. 1926)).

186. 253 N.Y.S. at 184.

187. Bryant Park Bldg. v. Abbott, 84 N.Y.S.2d 549, 550 (Mun. Ct. 1948); Cerana Apartments Corps. v. Solomon, 270 N.Y.S. 638, 639 (App. Term. 1934).

188. Nowey v. Kravitz, 51 A.2d 495, 496 (Conn. 1947); Nowey v. Kravitz, 14 Conn. Supp. 389, 389 (C.P. 1946); Union Commerce Bank v. Kimbro, 162 N.E.2d 926, 927 (Ohio Mun. Ct. 1959).

189. Van Leyden v. 360 E. 55th St. Corp., 39 F. Supp. 879, 879 (S.D.N.Y. 1941); cf. McCarthy v. Wynne, 126 F.2d 620, 623 (10th Cir. 1942) (enforcing a post-dispute jury-waiver agreement "in the nature of a private contract").

While Van Leyden relied upon a New York state precedent, one commentator argues that a subsequent Supreme Court ruling makes this no longer good practice.

In another early diversity case, Van Leyden v. 360 East 55th Street Corp., the judge applied New York state law in upholding a jury waiver in a lease. The court did not rely on any federal precedent, nor did it discuss any special requirements for the waiver to be voluntary, knowing, or in exchange for valid consideration. The reasoning of this decision was impliedly overruled by Simler $v$. Conner, which held that the question of a right to a jury trial is governed by federal, not state law. Although Van Leyden is a federal case, it is no longer authoritative for purposes of determining the proper federal standard for the enforcement of contractual jury waivers.

Matties, supra note 10, at 445 (citation omitted). Simler v. Conner, 372 U.S. 221 (1963), however, did not involve a jury-waiver clause. It did not even involve waiver of the jury-trial right. Simler involved the question whether a particular claim was legal (so that the jury-trial right would attach) or equitable (so that the jury-trial right would not attach). Id. at 221. The Court held that, even in a diversity case, federal rather than state law governs that determination. Id. at 222. The Court's statement that "the right to a jury trial in the federal courts is to be determined as a matter of federal law in diversity as well as other actions," $i d$. at 222 , should be read in that context.

190. See Shipley, supra note 179, at 1342-43 (citing cases).

191. Freeman v. Island Discount Corp., 169 N.Y.S.2d 830 (App. Div. 1958); Bonnie-Lassie Sportswear, Inc. v. Century Factors, Inc., 127 N.Y.S.2d 740 (App. Div. 1954).

192. Freeman involved a jury-waiver clause in a "chattel mortgage," the pre-Uniform Commercial Code equivalent of a security agreement. 
standard, but for reasons consistent with contract law and its standards of consent. ${ }^{193}$

\section{B. The Historical Connection Between Contract-Law Standards of Consent for Jury-Waiver and Arbitration Clauses}

Importantly, during this era, the case law on consent standards for jurywaiver clauses was consistent with that on consent standards for arbitration clauses. Arbitration cases also seem to have been centered in New York. ${ }^{194}$ And New York was the leader in enacting a modern arbitration statute-that is, a statute requiring courts to enforce predispute arbitration agreements. ${ }^{195}$ In fact, the FAA (which was enacted in 1925) was based on the New York Arbitration Act of $1920 .{ }^{196}$ Section 2 of the New York Act provided:

A provision in a written contract to settle by arbitration a controversy thereafter arising between the parties to the contract, or a submission hereafter entered into of an existing controversy to arbitration pursuant to title eight of chapter seventeen of the code of civil procedure, shall be valid, enforcible and irrevocable, save upon such grounds as exist at law or in equity for the revocation of any contract. ${ }^{197}$

Except for the spelling and placement of the word "enforceable," the New York Act's language was copied in section 2 of the FAA: "[such provisions] shall be valid, irrevocable, and enforceable, save upon such grounds as exist at law or in equity for the revocation of any contract." ${ }^{198}$ Thus, the FAA's adoption of contract law's standards of consent simply copied the New York Arbitration Act's adoption of contract law's standards of consent.

Soon after its enactment, the New York Arbitration Act was challenged as inconsistent with the jury-trial right granted by the New York state constitution. ${ }^{199}$ In an opinion by Judge Benjamin Cardozo, New York's highest court rejected this challenge, holding that "[t]he [jury-trial] right is one that may be waived. It was waived by the consent to arbitrate." ${ }^{200}$ Thus, Judge Cardozo and his colleagues apparently concluded that the New York Arbitration Act's contract-law standards of consent are consistent with the standards for waiving the New York Constitution's right to jury trial. Similarly, federal courts have consistently determined that the identical contract-law standards found in section 2 are consistent with the standards for waiving the federal constitutional right to jury trial. As discussed earlier, no published judicial decision has ever held section 2's contract-law standards inconsistent with the Seventh Amendment. ${ }^{201}$

193. For example, one case enforced the clause with respect to the landlord's action against the tenant who signed the lease, but not the landlord's action against the guarantor. See Garsau Realty Corp. v. Kohler, 282 N.Y.S. 822, 823 (Civ. Ct. 1935).

194. MACNEIL, supra note 69 , at 25 .

195. Id. at $25-47$.

196. Id. at 106.

197. 1920 N.Y. LAws $275 \S 2$ (codified as New York Civil Practice Act $\S 1448$ ).

198. 9 U.S.C. $\$ 2$ (2000); see MACNEIL, supra note 69, at 106.

199. Berkovitz v. Arbib \& Houlberg, Inc., 130 N.E. 288 (N.Y. 1921).

200. Id. at 291 (citations omitted).

201. See supra note 67 and accompanying text. 


\section{The Departure from Contract-Law Standards of Consent}

While arbitration cases continue to hold that contract-law standards of consent are consistent with the Seventh Amendment, the case law on jury-waiver clauses has departed from this view. Possible hints of this departure can be found in the case law from the 1940s through the $1960 \mathrm{~s},{ }^{202}$ but it was not until the 1970s that the departure from contract-law standards to knowing-consent standards really began.

During the 1960s and early 1970s, New York courts continued routine enforcement of jury-waiver clauses ${ }^{203}$ including those found in consumer form contracts. ${ }^{204}$ Additionally, courts outside New York were increasingly presented with, and chose to enforce, such clauses. ${ }^{205}$ The vast majority of cases from this era suggest no departure from contract-law standards of consent. For example,

202. The first case that arguably might be considered inconsistent with contract law was Klipack $v$. Raymar Novelties, Inc., 75 N.Y.S.2d 418 (App. Div. 1947). Klipack held that a lease jury-waiver clause did not cover tenants' statutory claims under rent control statutes enacted after the lease was formed. Id. at 419-20. Klipack might be considered an example of the rule of contract construction that ambiguities are construed against the drafter. See FARNSWORTH, supra 16, at 473-74 (stating that this rule is "especially common."); see also James Talcott, Inc. v. Le Bou Slax, 87 N.Y.S.2d 509, 511 (Sup. Ct. 1949) (stating that since a jury-waiver clause is "in derogation of rights[,] [it] is to be construed strictly against the drawer of the instrument").

The first published jury-waiver-clause opinion by a federal appeals court, Rodenbur v. Kaufmann, 320 F.2d 679 (D.C. Cir. 1963), also seems to be an example of this same rule. While the court acknowledged the general enforceability of jury-waiver clauses, $i d$. at 683 , it decided that the clause at issue did not cover the tenant's personal injury claim.

The clause, strictly construed as it must be, did not bar a jury trial as to rights which the tenant might have against the landlords unless issues with respect thereto arose out of or were in some way connected with the lease of her apartment. Such is the plain meaning of the language.

Id. at 684 (following Levy v. N.Y. Majestic Corp., 161 N.Y.S.2d 943 (App. Div. 1957)); accord Nat'l Acceptance Co. v. Myca Prods., Inc., 381 F. Supp. 269, 270 (W.D. Pa. 1974) (describing "the present case" as "similar" to Rodenbur and holding that "[a]pplication of the basic principle that ambiguities in a contract are construed against the drafting party supports the above construction of the waiver [that it does not cover the dispute] because plaintiff drafted the loan and security agreement").

203. See, e.g., Chem. Bank v. Summers, 413 N.Y.S.2d 148 (App. Div. 1979); A.J. Armstrong Co. v. Nechamkin, 388 N.Y.S.2d 618 (App. Div. 1976); Fay's Drug Co. v. P\&C Property Coop., 380 N.Y.S.2d 398 (App. Div. 1976); Massry Importing Co. v. Sec. Nat'1 Bank, 373 N.Y.S.2d 6 (App. Div. 1975); Franklin Nat'l Bank of Long Island v. Capobianco, 266 N.Y.S.2d 961 (App. Div. 1966); Estate of Greenberg v. Schefler, 425 N.Y.S.2d 909 (App. Term. 1979) (reversing a lower court's holding of unconscionability and holding that a lease waiving the jury-trial right was valid and binding); Ave. Assocs., Inc. v. Buxbaum, 373 N.Y.S.2d 814 (App. Term. 1975); Eisenberg v. 230 Kent Corp., 229 N.Y.S. 2d 109 (Sup. Ct. 1962); Riverbay Corp. v. Lattimore, 414 N.Y.S.2d 238 (Civ. Ct. 1979) (holding that a lease jury-waiver clause is "generally valid and binding unless a proceeding is brought within the purview of section 259-c of the Real Property Law[,] which renders null and void a jury lease waiver in an action for personal injuries or property damages"); Arol Dev. Corp. v. Goodie Brand Packing Corp., 372 N.Y.S.2d 324 (Civ. Ct. 1975); Lerner v. Rivera, 206 N.Y.S.2d 865 (Mun. Ct. 1960).

Some New York cases involved jury-waiver clauses that failed to satisfy a statutory requirement regarding font size. See, e.g., Koslowski v. Palmieri, 414 N.Y.S.2d 599 (App. Term. 1979); Sorbonne Apartments Co. v. Kranz, 409 N.Y.S.2d 83 (Civ. Ct. 1978).

204. David v. Mfrs. Hanover Trust Co., 298 N.Y.S.2d 847 (App. Term. 1969).

205. See, e.g., Smith-Johnson Motor Corp. v. Hoffman Motors Corp., 411 F. Supp. 670 (E.D. Va. 1975); Central Inv. Assocs., Inc. v. Leasing Serv. Corp., 362 So. 2d 702 (Fla. Dist. Ct. App. 1978); Azalea Drive-In Theatre, Inc. v. Sargoy, 214 S.E.2d 131 (Va. 1975). 
in 1969 the New York Appellate Division reversed a lower court's attempt to create a knowing-consent standard. ${ }^{206}$

The court below denied the motion to strike the jury demand upon the sole claim of the respondents that they had been unaware that each instrument contained a jury waiver provision. In so doing the court erred. "Ordinarily, the signer of a deed or other instrument, expressive of a jural act, is conclusively bound thereby. That his mind never gave assent to the terms expressed is not material." "Not to have read the contract or to have had it read to him before signing, if that be a fact as he testified, furnishes no basis for his repudiation of any of its terms."

The first reported decision to use a knowing-consent standard without being reversed seems to have been Colgate Construction Corp. v. Hill. ${ }^{208}$ This citycourt case involved a one-page form contract used by a home improvement contractor. The form had printing on both sides, with the place for the customer's signature on the front and the jury-waiver clause was on the back. ${ }^{209}$ The judge held that these facts "do not permit this court to find that defendants knowingly waived their rights to a jury trial." ${ }^{1210}$ This case appears to be the only unreversed case to require knowing consent before that requirement was imposed in 1977 by the Second Circuit in National Equipment Rental, Ltd. v. Hendrix. ${ }^{211}$

Hendrix is the "leading" case for those who advocate a knowing-consent requirement. ${ }^{212}$ It has been described as "one of the first cases to articulate a modern standard for the enforcement of contractual jury waivers. ${ }^{1213}$ Another way to put it is that the court in Hendrix had very little basis for its announcement of this "modern" standard. None of the cases cited in Hendrix even involved jury-waiver clauses. The Hendrix court wrote:

It is elementary that the Seventh Amendment right to a jury is fundamental and that its protection can only be relinquished knowingly and intentionally. Johnson v. Zerbst, [304 U.S. 458] (1938); Heyman v. Kline, 456 F.2d 123, 129 (2d Cir. 1972), cert. denied, [409 U.S. 847] (1972). Indeed, a presumption exists against its waiver. Aetna Insurance Co. v. Kennedy, [301 U.S. 389] (1937). There is little doubt that the provision relied on by NER fails to overcome this presumption. The waiver clause was set deeply and inconspicuously in the contract, and Justice Black, dissenting in National Equipment Rental, Ltd. v. Szukhent, [375 U.S. 311, 332-3] (1964), aptly characterized the nature of NER's form agreements:

this printed form provision buried in a multitude of words is too weak an imitation of a genuine agreement to be treated as a waiver of so important a constitutional safeguard ... it exhausts credulity to think that they or any other layman reading these legalistic words would have known or even suspected that they amounted to (such) an agreement....

A footnote followed:

206. James Talcott, Inc. v. Wilson Hosiery Co., 299 N.Y.S.2d 460 (App. Div. 1969).

207. Id., at 461 (citations omitted).

208. 334 N.Y.S.2d 1002 (Civ. Ct. 1972).

209. Id., at 1003.

210. Id., at 1004.

211. 565 F.2d 255 (2d Cir. 1977).

212. Sternlight, supra note Error! Bookmark not defined., at 678.

213. Matties, supra note 10, at 446. 
In Szukhent, the Supreme Court, by a 5-4 vote, upheld a provision in a similar contract providing that service of process could be made on an agent designated in the document. The right to a jury trial, however, is far more fundamental than the right to personal service, and cannot be waived absent a showing that its relinquishment is knowing and intentional. Fuentes v. Shevin, [407 U.S. 67] (1972) provides a compelling analogy. There, the Court refused to uphold a contractual provision waiving due process rights, noting that there was "no showing whatever that the appellants were actually aware or made aware of the significance of the fine print now relied upon as a waiver of constitutional rights." [Id. at 95]. No such showing has been made here. ${ }^{214}$

There is much here to criticize.

First, for the proposition that the jury-trial right "can only be relinquished knowingly and intentionally," the court cited a criminal case, Johnson, a case that involved an attorney's oral waiver during a pretrial conference, Heyman, and a case that involved a directed verdict, Aetna. ${ }^{215}$ As noted above, courts (including the Supreme Court) apply higher consent standards for constitutional waivers in the criminal context than in the civil context, and there are good reasons for doing so. ${ }^{216}$ Some of those reasons also make an oral waiver during litigation an inapt analogue to a jury-waiver clause found in a contract.

Second, the Hendrix court's treatment of Szukhent is flawed. The court provided no support for its assertion that the jury-trial right "is far more fundamental than the right to personal service" waived in Szukhent. ${ }^{217}$ "Waiver of service of process is equivalent to waiver of personal jurisdiction, which is a due process right." 218 Hendrix provides no authority or reasoning to explain why the standard for civil waivers of constitutional rights should differ when the right is found in the Seventh Amendment as opposed to the Due Process Clause.

Finally, the Hendrix court cited Fuentes without citing Mitchell or Bremen. As noted above, Fuentes "represents the last effort of the Warren Court Justices to stamp their views on contract into the Constitution," while Mitchell and Bremen are better indicators of modern constitutional law. ${ }^{219}$

Hendrix was already out of step with the Supreme Court when it was decided in 1977, and it is now farther out of step with a modern Supreme Court that has applied contract-law standards of consent in forum-selection cases such as Carnival Cruise and in arbitration cases such as Casarotto. ${ }^{220}$ Thus, the case for overruling the Hendrix court's knowing-consent requirement is strong. And although most federal courts since Hendrix have applied its knowing-consent

214. Hendrix, 565 F.2d at 258 \& n.1.

215. "The Hendrix court did not acknowledge that it was applying cases involving jury waivers that occurred during litigation to a situation in which the waiver was executed before any controversy between the parties arose." Matties, supra note 10, at 446.

216. See supra note 88 and accompanying text.

217. Hendrix, 565 F.2d at 258.

218. Matties, supra note 10, at 447 (critiquing Hendrix); see WRIGHT \& MILLER, supra note 123,

$\S 1074$ ("The decisions of the Supreme Court make it clear that the requirement of reasonable notice must be regarded as part of the constitutional due process limitations on the jurisdiction of a state or federal court.").

219. See supra Part V.B. (quoting Shell, supra note 97).

220. For other Supreme Court cases, see supra note 60. 
requirement, ${ }^{221}$ few of these are appellate courts. ${ }^{222}$ Furthermore, many state courts continue to use contract-law rather than knowing-consent standards even in "consumer" contexts such as residential leases and safe deposit boxes. ${ }^{223}$ Most importantly, the Supreme Court has yet to address the proper consent standards for waiver of Seventh Amendment rights. If and when the Supreme Court does reach the issue, it can overrule the Hendrix court's knowing-consent

221. See Sternlight, supra note Error! Bookmark not defined., at 678-79. An exception is Smyly v. Hyundai Motor America, 762 F. Supp. 428 (D. Mass. 1991) (enforcing a jury-waiver clause despite a lack of knowing consent). In some cases, it is not entirely clear whether the court is applying knowingconsent standards or contract-law standards. Professor Sternlight characterizes Telum, Inc. v. E.F. Hutton Credit Corp., 859 F.2d 835, 837 (10th Cir. 1988), as "citing, favorably, [a] standard that permits [the] waiver of [a] fundamental jury trial right that is knowing and intentional, while going on to uphold [the] waiver in [a] commercial loan." Sternlight, supra note Error! Bookmark not defined., at 678 n.43. However, Telum may not belong in the pro-Hendrix camp because it seems to rely, not "on facts such as inconspicuous fine print or a gross disparity in bargaining power," but rather "allegations of fraud in the inducement relating to the contract as a whole." Telum, 859 F.2d at 837; see Bonfield v. AAMCO Transmissions, Inc., 717 F. Supp. 589, 596 (N.D. Ill. 1989) (stating that the franchisee "knowingly and intelligently waived his right to a jury trial" without expressly stating that only knowing and intelligent waivers are enforceable). Cases like Bonfield are perhaps analogous to the Supreme Court's opinion in Overmyer, which found that the knowing-consent standard was satisfied and thus that the Court did not need to decide whether that, or a more lenient standard, was controlling.

222. See Leasing Serv. Corp v. Crane, 804 F.2d 828, 832 (4th Cir. 1986) (holding that the jury-trial right "is one that can be knowingly and intentionally waived by contract"); K.M.C. Co., Inc. v. Irving Trust Co., 757 F.2d 752, 756 (6th Cir. 1985).

One of these cases, K.M.C. Co., Inc. v. Irving Trust Co., deserves comment. First, K.M.C. is "[t]he perhaps most debated lender liability case." A. Brooke Overby, Bondage, Domination, and the Art of the Deal: An Assessment of Judicial Strategies in Lender Liability Good Faith Litigation, 61 FordHAM L. REV. 963, 997 (1993). As Professor Overby puts it, K.M.C. was "the vanguard of pro-borrower forces," which created an "outcry" and a "backlash against it." Id. at 969, 970, 1002. Professor Overby cites a long list of cases questioning K.M.C. Id. at nn.29, 230.

With respect to the jury-waiver clause, the K.M.C. Court emphasized the debtor's contention that "it was represented to [debtor]'s president Butler before the signing of the financing agreement that the jury-waiver provision would not be enforced under circumstances such as those in the instant case," so "[t]his case is not like [cases] in which the party seeking to escape the waiver provision claimed that it did not intend or understand that in signing the contract there at issue it was waiving jury trial." 757 F.2d at 757. Finally, K.M.C. incorrectly states that "[t]hose cases in which the validity of a contractual waiver of jury trial has been in issue have overwhelmingly applied the knowing and voluntary standard." Id. at 756. While that may be true of post-Hendrix cases, it is not true (as Parts VI.A.-B. of this Article show) of the whole class of jury-waiver cases dating back to the 1920s.

223. See, e.g., L\&R Realty v. Conn. Nat'l Bank, 715 A.2d 748, 753 (Conn. 1998); Gelco Corp. v. Campanile Motor Serv., Inc., 677 So. 2 d 952 (Fla. Dist. Ct. App. 1996); Vista Centre Venture v. Unlike Anything, Inc., 603 So. 2d 576 (Fla. Dist. Ct. App. 1992); Palomares v. Ocean Bank of Miami, 574 So. 2d 1159, 1160 (Fla. Dist. Ct. App. 1991); Credit Alliance Corp. v. Westland Mach. Co., Inc., 439 So. 2d 332, 333 (Fla. Dist. Ct. App. 1983) ("Although the record demonstrates that he never read the contract, Westland's president cannot now be heard to complain of its terms. He is bound by the contract which he signed."); Chase Commercial Corp. v. Owen, 588 N.E.2d 705, 709 (Mass. App. Ct. 1992) ("[F]ederal cases ... seem to impose a somewhat stricter standard.... They require that any waiver be knowing and intentional."); Uribe v. Merchs. Bank of N.Y., 642 N.Y.S.2d 23 (App. Div. 1996) (discussing safe deposit box rental); Barclays Bank of N.Y., N.A. v. Heady Elec. Co., Inc., 571 N.Y.S.2d 650, 653 (App. Div. 1991) ("[E]ven if Heady had neglected to read the documents containing the waiver provisions, this alone would not affect their validity."); Drelich v. Kenlyn Homes, Inc., 446 N.Y.S.2d 409 (App. Div. 1982); Estate of Greenberg v. Schefler, 425 N.Y.S.2d 909 (App. Term 1979); Jossel v. Filicori, 547 N.Y.S.2d 1005 (Sup. Ct. 1989) (discussing a residential lease); King Enters., Ltd. v. O'Connell, 660 N.Y.S.2d 283 (Civ. Ct. 1997) (discussing a residential lease); Truck World, Inc. v. Fifth Third Bank, Nos. C-940029, C-940399, 1995 WL 577521 (Ohio Ct. App. Sept. 29, 1995); TS1 P'ship v. Allred, 877 P.2d 156, 160-61 (Utah Ct. App. 1994). 
requirement and thus harmonize the law on jury-waiver clauses with that of other civil waivers of constitutional rights.

\section{VII}

\section{CONSLUSION: HARMONIZING THE LAW ON CIVIL WAIVERS OF CONSTITUTIONAL RIGHTS}

There is an appeal to harmonizing the law on civil waivers of constitutional rights. ${ }^{224}$ Harmonization could occur in two ways-either by making jury-waiver cases conform to arbitration law, property-deprivation cases, forum-selection cases, and consent-to-jurisdiction cases, or by making these latter cases all conform to jury-waiver cases. It seems more likely that the Supreme Court will choose the first approach, which would require overruling none of its own cases and only a few federal appeals court cases. ${ }^{225}$ In contrast, the second approach would require (1) overruling the holdings of many of the forum-selection and consent-to-jurisdiction cases decided since Bremen and Carnival Cruise ${ }^{226}$ (2) casting doubt on property-deprivation cases since Mitchell and Doehr and perhaps on the basic law of secured transactions; ${ }^{227}$ and (3) holding unconstitutional a seventy-nine-year-old federal statute, FAA section $2 .{ }^{228}$ In other words, the second approach to harmonizing the law on civil waivers of constitutional rights would require upsetting the law in a variety of doctrinal areas. It is therefore unlikely the Court will hold that the Seventh Amendment requires a knowing-consent standard for arbitration agreements. It is more likely, and more desirable ${ }^{229}$ that the Court will overrule the Hendrix court's knowing-consent requirement for jury-waiver clauses and thus harmonize the law on civil waivers of constitutional rights.

224. While harmonization is appealing, it is also possible that different types of Seventh Amendment waivers should continue to be governed by different standards of consent. See supra note 10.

225. See supra Part VI.C.

226. See supra Parts V.C-D.

227. See supra Part V.B.

228. See supra Part IV. Relatedly, it would require confining Casarotto to state-court cases (in which the Seventh Amendment does not apply) and overruling federal cases that applied Casarotto to preempt state laws requiring standards of consent higher than those of contract law. See, e.g., Morrison v. Colo. Permanente Med. Group, P.C., 983 F. Supp. 937, 943 (D. Colo. 1997) (holding that the Colorado Health Care Availability Act's "medical services arbitration provisions are 'inconsonant' with, and therefore preempted by, the Federal Arbitration Act"). This would produce the bizarre result of such state laws applying in federal court but not in state court because in state court the FAA would, unconstrained by the Seventh Amendment, continue to preempt such laws.

229. For a normative argument that arbitration agreements should be governed by contract-law standards of consent rather than knowing consent, see Ware, supra note 66, at 218-21. 